\title{
Review \\ Control of ABA Signaling and Crosstalk with Other Hormones by the Selective Degradation of Pathway Components
}

\author{
Agnieszka Sirko*D, Anna Wawrzyńska *D, Jerzy Brzywczy and Marzena Sieńko \\ Laboratory of Plant Protein Homeostasis, Institute of Biochemistry and Biophysics, Polish Academy of Sciences, \\ ul. Pawinskiego 5A, 02-106 Warsaw, Poland; jurek@ibb.waw.pl (J.B.); marsi@ibb.waw.pl (M.S.) \\ * Correspondence: asirko@ibb.waw.pl (A.S.); blaszczyk@ibb.waw.pl (A.W.)
}

check for updates

Citation: Sirko, A.; Wawrzyńska, A.; Brzywczy, J.; Sieńko, M. Control of ABA Signaling and Crosstalk with Other Hormones by the Selective Degradation of Pathway Components. Int. J. Mol. Sci. 2021, 22, 4638. https://doi.org/10.3390/ijms22094638

Academic Editor: Sławomir Borek

Received: 8 April 2021

Accepted: 26 April 2021

Published: 28 April 2021

Publisher's Note: MDPI stays neutral with regard to jurisdictional claims in published maps and institutional affiliations.

Copyright: (c) 2021 by the authors. Licensee MDPI, Basel, Switzerland. This article is an open access article distributed under the terms and conditions of the Creative Commons Attribution (CC BY) license (https:// creativecommons.org/licenses/by/ $4.0 /)$.

\begin{abstract}
A rapid and appropriate genetic and metabolic acclimation, which is crucial for plants survival in a changing environment, is maintained due to the coordinated action of plant hormones and cellular degradation mechanisms influencing proteostasis. The plant hormone abscisic acid (ABA) rapidly accumulates in plants in response to environmental stress and plays a pivotal role in the reaction to various stimuli. Increasing evidence demonstrates a significant role of autophagy in controlling ABA signaling. This field has been extensively investigated and new discoveries are constantly being provided. We present updated information on the components of the ABA signaling pathway, particularly on transcription factors modified by different E3 ligases. Then, we focus on the role of selective autophagy in ABA pathway control and review novel evidence on the involvement of autophagy in different parts of the ABA signaling pathway that are important for crosstalk with other hormones, particularly cytokinins and brassinosteroids.
\end{abstract}

Keywords: abscisic acid; autophagy; brassinosteroids; cytokinins; hormone crosstalk; ubiquitin

\section{Introduction}

Plants are often subjected to various detrimental environmental stressors. Despite their sessile lifestyle, plants are able to maintain their internal equilibrium when exposed to external challenges. This balance, called homeostasis, can be achieved by internal mechanisms that alter cell metabolism, thanks to which the whole organism can maintain relatively constant conditions. Such rapid and appropriate genetic and metabolic acclimation, which is a crucial issue for plants' survival, is maintained due to the coordinated action of plant hormones and cellular degradation mechanisms influencing proteostasis.

Protein homeostasis (or proteostasis) integrates cellular pathways that mediate biogenesis, folding, trafficking, and the degradation of polypeptides to maintain the required concentrations of all proteins that compose the proteome. This field has been intensively investigated by numerous research groups [1]. Proteins are often tagged for removal by ubiquitination. Polyubiquitinated proteins and protein aggregates are degraded via the ubiquitin-proteasome system (UPS) pathway and via the autophagy-vacuolar route. The UPS pathway is restricted in its ability to degrade aggregated proteins, which are too large to pass through the narrow proteasome entrance channel [2]. Thus, autophagy represents a major mechanism in plants for degrading macromolecular ubiquitinated protein aggregates as a response to stressors [3,4]. There is growing evidence that these two degradation systems are interconnected and form an integrated quality control network in response to general cellular stress [5]. Many reviews summarize the significance of ubiquitination in plant stress responses [6-8].

Phytohormones are not only involved in protein degradation mechanisms, but also play a pivotal role in plant responses to various stimuli. Although the relationships between them are poorly understood, it is generally accepted that extensive crosstalk and multiple regulatory loops are responsible for maintaining the balance of growth and stress responses [9]. 
Phytohormones are master regulators of plant growth, development, and stress response. Of them, abscisic acid (ABA) is rapidly accumulated in plants in response to abiotic stress [10]. Similarly to most other hormones, ABA is involved in developmental processes, including seed maturation, seed dormancy and germination, primary root growth, and flowering time control, and in the response to adverse environmental stressors [10,11]. Plants exposed to abiotic stress quickly activate the ABA signaling cascade, resulting in the activation of ABA-responsive transcription factors and the induction of ABA-responding genes. However, after achieving stress tolerance, it is necessary to terminate (or attenuate) the ABA pathway. The balance is maintained by the selective degradation of specific components of the ABA signaling pathway upon their tagging for decay by ubiquitination. Conventional degradation of the tagged components takes place via the proteasome; however, increasing evidence demonstrates a significant role of autophagy in controlling ABA signaling [9,12-16]. In addition to this interplay with degradation systems, an additional layer of complexity is provided by extensive crosstalk between ABA and other phytohormones [17-20].

The above issues have been frequently reviewed; however, although the field has been extensively investigated, new discoveries are constantly being provided. The purpose of this review is to update information on the selective degradation of components of the ABA signaling pathway, particularly on the control of ABA-responsive transcription factors and the role of selective autophagy in ABA pathway control. We also reviewed novel evidence on the involvement of autophagy in different parts of the ABA signaling pathway that are important for crosstalk with other hormones, particularly cytokinins and brassinosteroids.

\section{Principles of ABA Perception and Signaling and Their Control by Selective Degradation Systems}

Reversible protein phosphorylation is a post-translational modification catalyzed by protein kinases and phosphatases. It acts as a molecular switch for almost all key events of cell metabolism and signaling in eukaryotes. Additionally, in the field of ABA signal transduction, protein kinases and phosphatases play pivotal roles, forming a reversible protein phosphorylation cascade, including $\mathrm{ABA}$ receptors (pyrabactin resistance/regulatory components of $\mathrm{ABA}$ receptor (PYR/RCAR)), type $2 \mathrm{C}$ protein phosphatases (PP2Cs), protein kinases (Snf1 (sucrose-non-fermentation 1)-related kinases subfamily 2, SnRK2s), and downstream targets. The key function of RCARs is to indirectly control the activity of SnRK2s, which phosphorylate numerous stress-activated targets in the response to ABA, including ABA-responsive transcription factors (TFs) [21,22]. This is accomplished through a negative regulatory pathway, involving RCARs, PP2C, and SnRK2 proteins and E3 ubiquitin ligases (Figure 1).

When ABA accumulates in cells in response to environmental stress or developmental cues, ABA binds to RCARs and triggers a conformational change that allows the binary complex (receptor-ABA) to physically interact with PP2Cs and inhibit its phosphatase activity. The various RCAR-PP2C heterodimers preclude binding of SnRK2s to PP2Cs, thus stimulating SnRK2s kinase activity. Consequently, SnRK2s are released to phosphorylate and control the activity of downstream factors to trigger physiological responses [23].

Several studies have suggested that plant responses to ABA are complemented by the enhanced degradation of PP2Cs by different E3 ligases (i.e., U-box type, RING type, and multimeric CRL type), which can facilitate ABA signaling and play an important role in preventing the excessive accumulation of PP2Cs. However, E3 ligases are not only able to enhance $\mathrm{ABA}$ signaling, but also facilitate the resetting of $\mathrm{ABA}$ signaling when tolerance to the stressor has been achieved [12]. 


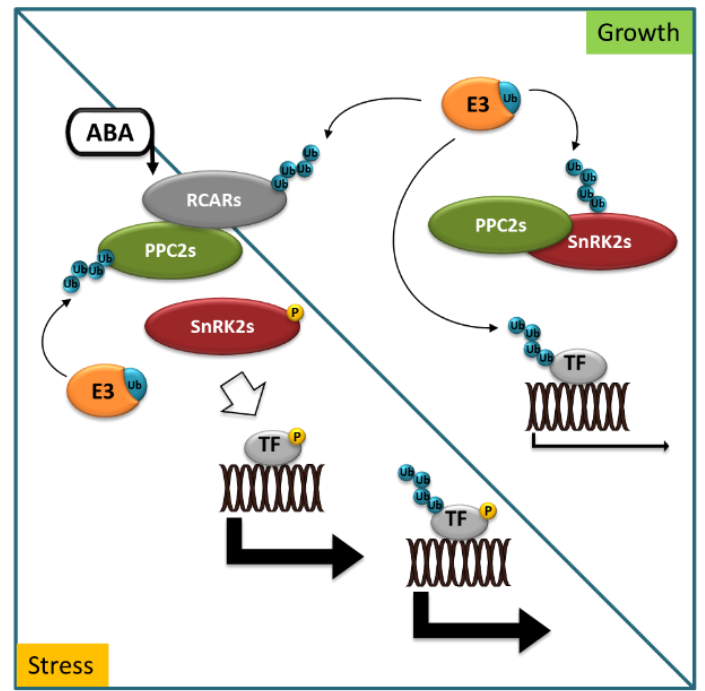

Figure 1. Abscisic acid (ABA) signaling in stress and growth. In growth-promoting conditions, $A B A$ receptors (RCARs), protein kinases (SnRK2s) dephosphorylated by type $2 \mathrm{C}$ protein phosphatases (PP2Cs), and ABA-responsive transcription factors (TF) are marked for degradation with ubiquitin $(\mathrm{Ub})$ by specific E3 ligases (E3). In stress conditions, ABA accumulates and binds to RCARs, allowing for interaction with PP2Cs to inhibit phosphatase activity. SnRK2s are released to phosphorylate and control the activity of downstream targets to trigger physiological responses. Blue circles indicate ubiquitination, yellow circles indicate phosphorylation events.

\section{Role of Ubiquitination and Selective Degradation in ABA Perception and Signaling}

Ubiquitination is (next to phosphorylation) another reversible, post-translational modification, originally discovered as a critical element in highly regulated proteolysis and regarded as essential for many other cellular processes. Ubiquitin (Ub) serves as a reusable tag that decides the cellular fate of the proteins and is recognized by numerous $\mathrm{Ub}$-binding proteins directing the target proteins for selective turnover [24-26]. Ub, often in the form of polymeric chains, is covalently attached to the target proteins through a three-step E1-E2-E3 conjugation cascade (Figure 2).

The process starts with E1 (or Ub-activating enzyme) in which $\mathrm{Ub}$ is activated in an ATP-dependent manner, through a thioester bond between the C-terminus of $\mathrm{Ub}$ and a cysteine residue of $\mathrm{E} 1$, and next the thioester-linked $\mathrm{Ub}$ is transferred onto a cysteine residue of $\mathrm{E} 2$ (or $\mathrm{Ub}$-conjugating enzyme) by transesterification to form an unstable $\mathrm{E} 2-\mathrm{Ub}$ intermediate. Next, E2 enzymes catalyze the attachment of $\mathrm{Ub}$ to lysine (Lys) residues of target proteins using an E3 (or Ub ligase). E3 enzymes are responsible for substrate recognition and either directly transfer the $\mathrm{Ub}$ to the substrates from $\mathrm{E} 2$ or form an $\mathrm{E} 3-\mathrm{Ub}$ intermediate prior to the transfer. In successive rounds, additional $\mathrm{Ub}$ moieties can be attached to one of the seven lysine residues (Lys6, Lys11, Lys27, Lys29, Lys33, Lys48, and Lys63) or the N-terminal methionine (Met1) of $\mathrm{Ub}$ to produce poly-Ub chains. The endproduct is a $\mathrm{Ub}$-protein conjugate that contains an isopeptide bond between the $\mathrm{C}$-terminal glycine residue of $\mathrm{Ub}$ and one of the Lys residues in the substrate. These structurally distinct ubiquitylation patterns are recognized by various effector proteins harboring a ubiquitin-binding domain (UBD) to result in diverse downstream signals. For example, poly-Ub chains are linked by Lys 48 target substrates to the $26 \mathrm{~S}$ proteasome for degradation, whereas poly-Ub chains are linked by Lys63 direct substrates to autophagosomes, both with the concomitant release of $\mathrm{Ub}$ moieties for reuse [27]. 


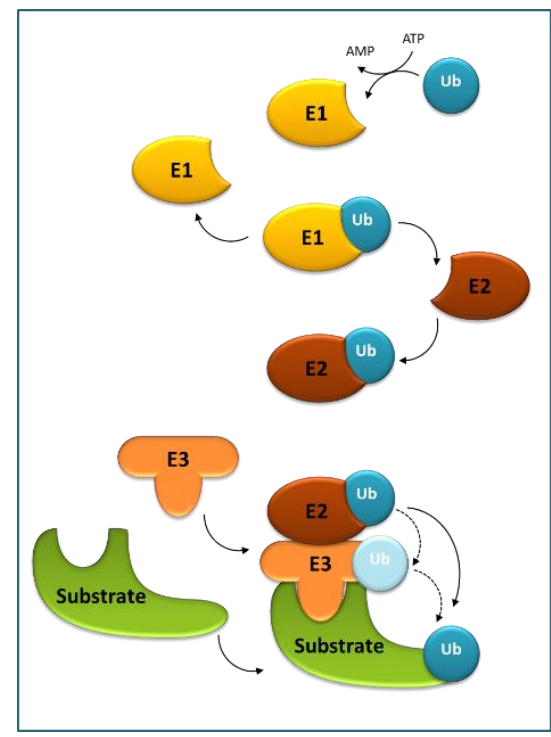

Figure 2. The ubiquitination cascade. Ubiquitin-activating enzyme (E1) activates ubiquitin (Ub) in an ATP-dependent manner, and next the thioester-linked $\mathrm{Ub}$ is transferred to Ub-conjugating enzyme (E2). Subsequently, E2 enzymes catalyze the attachment of $\mathrm{Ub}$ to a substrate using Ub ligase (E3). E3s, responsible for substrate recognition, transfer $\mathrm{Ub}$ either directly from E2 or form an E3-Ub intermediate prior to the transfer.

The E3 Ub ligases can be classified into single- and multi-subunit groups [28]. The single-subunit group includes several subfamilies based upon their mechanisms of action and the presence of specific domains: HECT (homology to E6-AP C terminus), RING (really interesting new gene), and U-box type E3s. The multi-subunit group, cullin-RING box1-ligases (CRLs), are further divided into four subfamilies: SCF (S phase kinaseassociated protein 1-cullin 1-F-box), BTB (Bric-a-brac-Tramtrack-Broad complex), DDB (DNA damage-binding domain-containing), and APC (anaphase-promoting complex).

Three E2 enzymes, UBC32, UBC33, and UBC34 play a negative role in drought stress response and $A B A$ signaling [29], and numerous E3 ligases are involved in the inhibition of $\mathrm{ABA}$ signaling in optimal conditions, $\mathrm{ABA}$ induction upon environmental stress, and ABA attenuation after achieving stress tolerance [12]. The currently known components of ABA perception and signaling and E3 ligases involved in the process are listed in Table 1.

\subsection{E3 in ABA Perception and ABA Signaling Cascade}

The E3 ligases involved in controlling the ABA signaling pathway, as well as their targets (Table 1), are linked together, creating a large network of interactions (Figure 3). When dividing this network according to a functional group of E3 targets, it can be observed that the majority of E3s are highly selective with respect to their targets and are usually limited to a single functional group of the ABA signaling pathway. This is particularly evident in the case of SnRK2s, where only two 'E3-target' pairs have been identified thus far, namely, HOS15 ubiquitinates SnRK2.6/OST1, while PP2-B11 ubiquitinates SnRK2.3. It is not clear whether so few $\mathrm{Ub}$ ligases controlling SnRK2s results from the paucity of experimental data, or if this signaling step is weakly controlled at the level of protein ubiquitination. 
Table 1. ABA pathway components targeted by E3 ligases.

\begin{tabular}{|c|c|c|}
\hline Pathway Component & Specific Target & E3 Ligase [References] (Remarks) \\
\hline \multirow{4}{*}{ ABA Receptors } & RCAR1/PYL9 & DDA1 [30]; REA1 [31]; PUB22 [32]; PUB23 [32] \\
\hline & RCAR3/PYL8 & RIFP1 [33]; DDA1 [30] \\
\hline & RCAR10/PYL4 & $\begin{array}{c}\text { DDA1 [30]; RSL1 [34]; UBC26 (E2)-RFA4 (E3) } \\
\text { [35]; RFA1 [35] }\end{array}$ \\
\hline & RCAR11/PYR1 & RSL1 [34]; RFA1 [35]; RFA4 [35] \\
\hline \multirow{8}{*}{ Type $2 \mathrm{C}$ protein phosphatases ( $\mathrm{PP} 2 \mathrm{C}$ ) } & ABI1 & $\begin{array}{c}\text { PUB12 [36]; PUB13 [36]; BPM3 [37]; BPM5 [37]; } \\
\text { UBC27/AIRP3 [38]; COP1 [39] }\end{array}$ \\
\hline & $\mathrm{ABI} 2$ & RGLG1 [40]; RGLG5 [40] \\
\hline & HAB1 & ВРМ3 [37]; BPM5 [37] \\
\hline & HAB2/NHL29 & RGLG1 [40]; RGLG5 [40] \\
\hline & AHG1 & PIR1.2 [41]; PIR2 [41] \\
\hline & AHG3/PP2CA & $\begin{array}{c}\text { RGLG1 [40]; RGLG5 [40]; PIR1.2 [41]; PIR2 [41]; } \\
\text { COP1 [39]; BPM3 [37]; BPM5 [37] }\end{array}$ \\
\hline & HAI1/SAG113 & PIR1.2 [41]; PIR2 [41] \\
\hline & HAI3 & PIR1.2 [41]; PIR2 [41] \\
\hline SnRK2 kinases & $\begin{array}{l}\text { SnRK2.3/SRK2I } \\
\text { SnRK2.6/OST1 }\end{array}$ & $\begin{array}{l}\text { PP2-B11 [42] } \\
\text { HOS15 [43] }\end{array}$ \\
\hline \multirow{11}{*}{ ABA-responsive transcription factors } & ABI5 & $\begin{array}{l}\text { DWA1 [44]; DWA2 [44]; KEG [45]; ABD1 [46]; } \\
\text { COP9 [47] }\end{array}$ \\
\hline & $\mathrm{ABI} 3$ & AIP2 $[48,49]$ \\
\hline & ABI4 & COP1 [50] \\
\hline & ABF1 & KEG $[51,52]$ \\
\hline & ABF2/AREB1 & KEG [53] \\
\hline & ABF3/AREB2 & KEG [51,52] \\
\hline & DREB2 & DRIP1 [54]; DRIP2 [54]; BPM2 [55] \\
\hline & HB6 & BTB1-6/BPM1-6 [56] \\
\hline & MYB96 & MIEL1 [57] (Myb96 activates ABI4) \\
\hline & MYB30 & RHA2b [58]; MIEL1 [57,59] \\
\hline & RAV1 & BPM1 $[60,61]$ \\
\hline \multirow{6}{*}{$\begin{array}{l}\text { Other regulatory and signaling } \\
\text { factors and ABA-responding genes }\end{array}$} & ADA2B & SKIP24/At1g08710 [62] \\
\hline & ATP1/SDIRIP1 & $\begin{array}{l}\text { AIRIP2 [63,64]; AIRP1 [63,64]; SDIR1 [65]; } \\
\text { (SDIRIP1 activates ABI5) }\end{array}$ \\
\hline & ACD11 & $\begin{array}{l}\text { XBAT35.2 [66]; (ACD11 is one of } \\
\text { ABA-responding genes) }\end{array}$ \\
\hline & RD21 & $\begin{array}{l}\text { AIRP3/LOG2 [67]; (positive role in ABA } \\
\text { responses; RD21 is Cys protease) }\end{array}$ \\
\hline & CIPK26 & KEG $[68,69]$ \\
\hline & PP2A & CHIP [70] \\
\hline
\end{tabular}




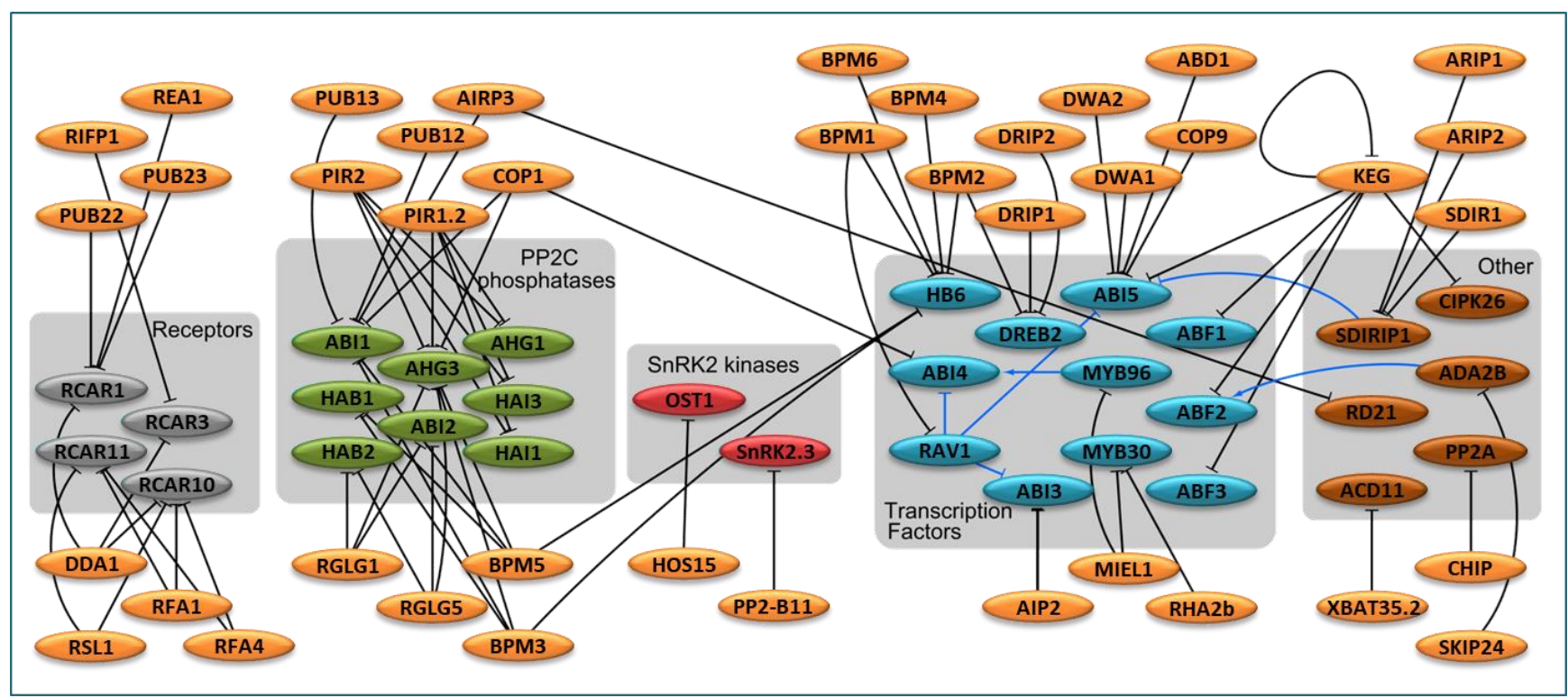

Figure 3. The network of E3 ligases and their targets involved in ABA signaling. E3 ligases are shown in orange, and their targets in ABA signaling pathway are colored according to target protein function (receptors in gray, PP2C phosphatases in green, transcription factors in blue, and other related components in terracotta). Different groups of target proteins are also shaded and labeled. Activation is shown by arrows, and inhibition by T-shaped bars. Black lines show interactions between proteins, while blue lines denote transcriptional control. The references are provided in Table 1.

At least eight E3 ligases were found to target at least four ABA receptors (Figure 3). Although some of them have two or three known targets, they exclusively target ABA receptors and no other element of the ABA signaling pathway.

The interaction network becomes slightly more complex for the eight PP2Cs, having known interactions with 10 E3s (Figure 3). Although all eight PP2Cs are targeted by more than one $\mathrm{Ub}$ ligase, and most of these E3s target more than one protein in the ABA signaling pathway, only four of these E3s interact with proteins other than PP2Cs. Three E3 ligases are common for some PP2Cs and two transcription factors involved in the ABA response.

Thus far, 11 transcription factors, involved in regulation by ABA, were found to be targeted by 17 E3 ligases (Figure 3). Among them, 13 are specific to transcription factors and they usually target only one or two proteins. Transcription factor HB6 is under the control of six BPM Ub ligases (BPM1-6). Transcription factor ABI5 is directly controlled by ubiquitination by five Ub ligases (DWA1, DWA2, ABD1, COP9, and KEG). ABI5 is also controlled at the transcriptional level by RAV1 and SDIRIP1, which are controlled by ubiquitination. The Ub ligase KEG controls four transcription factors (ABI5, ABF1, ABF2, and ABF3) and kinase CIPK26; thus, KEG appears to be one of the most important ligases controlling the ABA signaling pathway.

\subsection{E3 in ABA-Responsive Transcription Factors}

$\mathrm{Ub}$-mediated protein degradation can affect the gene expression needed to mitigate the potential negative effects of environmental stress by modulating the abundance of transcription factors. Additionally, under non-stress conditions, E3 ligases may prevent transcription by targeting the transcription factor for degradation. Transcriptional changes of ABA-responsive genes are mediated by a number of transcription factors, including members of the basic leucine zipper (bZIP), AP2/ERF, R2R3, and B3 families [10]. The abundance of many of these transcription factors is strictly guarded by numerous E3 ligases (Figure 3, Table 1).

\subsubsection{E3 Directly Binding ABA-Responsive Transcription Factors}

A RING-type E3 ligase, ABI3-INTERACTING PROTEIN 2 (AIP2), was the first E3 ligase to be implicated in the regulation of ABA signaling because it mediates ABSCISIC 
ACID INSENSITIVE 3 (ABI3) ubiquitination and its destruction through the $26 \mathrm{~S}$ proteasome $[48,49]$. The abundance of AIP2 transcripts increases in response to ABA and corresponds well with the decrease in ABI3 protein levels. The aip2 mutant was found to have higher levels of ABI3 and be hypersensitive to ABA. The ortholog of AIP2, OsDSG1 (DELAYED SEED GERMINATION 1), has been described in rice [71]. It also physically interacts with OsABI3 and has E3 Ub ligase activity, while negatively regulating tolerance to salt and drought stress.

Although ABI4 was initially demonstrated to act as a positive regulator in the ABA signaling cascade, several studies have revealed that it is involved in the control of a variety of other cascades and crosstalk among several phytohormones [72]. ABI4 either stimulates or represses the transcription of its target genes, which is consistent with its diverse biological functions. Due to the ABI4 protein's instability [73], the E3 ligases that are directly responsible for its degradation have remained elusive thus far. ABI4, together with ELONGATED HYPOCOTYL 5 (HY5), have been described to form an antagonistic module that controls seedling and chloroplast development during the transition from dark to light [49]. ABI4 promotes and HY5 inhibits the expression of CONSTITUTIVE PHOTOMORPHOGENIC 1 (COP1), the main repressor of photomorphogenesis. In turn, to ensure proper crosstalk between ABI4 and HY5 during the seedling greening process, COP1 targets ABI4 and HY5 for degradation in light and dark conditions, respectively. COP1 promotes ABI4 degradation, as evidenced by in vitro pull-down and in vivo coimmunoprecipitation assays [50].

The well-studied ABI5 is a nucleo-cytoplasmic bZIP-type transcription factor that acts downstream of ABI3. A monomeric RING-type E3 and two CUL4-RING E3 ligase (CRL) complexes have been implicated in controlling ABI5 stability and attenuating ABA signaling. CRL complexes, which are the largest class of Ub-modification enzymes in Arabidopsis, consist of a scaffold protein, one cullin protein, and an adaptor protein responsible for substrate recruitment [74]. DWD HYPERSENSITIVE TO ABA1 and ABA2 (DWA1 and DWA2, respectively) and ABA-HYPERSENSITIVE DCAF 1 (ABD1), the substrate receptors in CRLs, are able to recognize ABI5 in the nucleus to negatively regulate its stability via ubiquitination and subsequent proteasomal degradation [44,46]. Both dwa1dwa2 double mutants and abd1 mutants displayed ABA-hypersensitive phenotypes during seed germination and seedling growth and exhibited an accumulation of ABI5 following exposure to the hormone [46]. ABI5 did not accumulate in the dwa1dwa2 mutant in the absence of $\mathrm{ABA}$, which agrees with CRL being required to regulate transcription factor abundance in the presence of the hormone. Importantly, in the absence of ABD1, proteasome-dependent degradation of ABI5 after the removal of ABA is slower, implying that the E3 ligase is involved in the termination of ABA responses [46]. ABI5 is also targeted by $\mathrm{Ub}$-dependent proteolysis by a RING-type E3 ligase KEEP ON GOING (KEG) [45]. There is a feedback loop between ABA signaling, KEG, and ABI5, in which KEG promotes ABI5 degradation to suppress $\mathrm{ABA}$ signaling, while $\mathrm{ABA}$ accelerates KEG self-ubiquitination and degradation, resulting in $\mathrm{ABI} 5$ accumulation and $\mathrm{ABA}$ response promotion. $\mathrm{KEG}$ is localized to the trans-Golgi network/early endosome; therefore, it is believed that KEG marks ABI5 for degradation before it reaches the nucleus and activates ABA responses [52]. Additionally, another element that regulates ABI5 protein turnover is ABI FIVE BINDING PROTEIN (AFP) [75]. AFP belongs to a small family of proteins, AFP1-4, that can interact with ABI5. Although AFP is not an E3 ligase per se, it facilitates ABI5 proteasomal degradation in nuclear bodies, however the precise mechanism is not known. In rice, the AFP orthologue MEDIATOR OF OsBZIP46 DEACTIVATION AND DEGRADATION (MODD) interacts with the ABI5 orthologue OsbZIP46 to promote its ubiquitination by the E3 ligase OsPUB70, stopping ABA signaling [76]. Recently, another layer of regulation was discovered for ABI5 stability. The COP9 signalosome (CSN) regulates seed germination by facilitating ABI5 degradation [47]. CSN is a multi-subunit protein complex that may either inhibit or promote CRL complex activity. The CSN5A subunit was shown to interact with ABI5; however, the precise mechanism by which CSN5A regulates ABI5 stability will be a challenge for 
future studies. Finally, post-translational modifications of ABI5, such as phosphorylation and SUMOylation, may also play a role in ABI5 proteasomal turnover $[75,77,78]$.

In addition to ABI5, KEG also targets two other bZIP transcription factors, ABREBINDING FACTORS (ABF) 1 and ABF3, for degradation [51]. ABF1 and ABF3, which are also involved in seed germination and stress responses, are stabilized by ABA. Other $\mathrm{ABF}$, including $\mathrm{ABF} 2$ and $\mathrm{ABF} 4$, may also be involved in the KEG-mediated degradation pathway. The phenotype of KEG mutants is quite severe compared to other ABA mutants, and growth arrest occurs soon after germination in the absence of the hormone [68]. This lethality of the KEG mutation might be explained by the fact that KEG targets multiple components (CIPK26, ABI5, and ABF1/3) of the ABA signaling pathway. The accumulation of its substrates may lead to the misregulation and activation of other pathways independent of ABA [68].

DEHYDRATION-RESPONSIVE ELEMENT-BINDING PROTEIN 2A (DREB2A) is a key transcription factor controlling the expression of numerous genes responsive to drought, heat, and salt $[79,80]$. DREB2A only accumulates in transgenics capable of attaching Ub molecules to DREB2A in non-stress conditions within the nucleus [54]. DREB2A is stable in drip1drip2 double mutants, which present significantly higher survival rates in response to dehydration [54,81]. The situation is different under stress conditions, where the nuclear-localized A20/AN1-type zinc finger protein, STRESS ASSOCIATED PROTEIN 5 (SAP5), functions as an E3 ligase that promotes the degradation of DRIP1/2 to release and stabilize DREB2A [82]. Notably, SAP5 shows a preference for adding linear and Lys63-linked chains compared to Lys48-linked chains [83]. This emphasizes the potential role of SAP5 in the selected trafficking of polyubiquitinated proteins to other $26 \mathrm{~S}$ proteasome degradation systems, such as autophagy. DREB2A abundance increases upon exposure to heat stress. However, to attenuate the stress response, the level of the transcription factor gradually decreases over time due to the interaction with a MATH DOMAIN-CONTAINING BTB PROTEIN (BPM), which functions as a DREB2A receptor in a Cul3 BPM1-6 RING E3 ligase complex [55]. DREB2A contains a 30-amino acid serine threonine-rich region, referred to as the NEGATIVE REGULATORY DOMAIN (NRD), which is necessary for Cul3 BPM1-6 RING-depended degradation. Biochemical data proved that the NRD domain, by itself, is capable of adequately interacting with BPM proteins. Deletion of the NRD increases DREB2A stability and carries on its constitutive action in improving tolerance to drought and heat stress [79]. To add further complexity, a recent study discovered that SUMO has a positive regulatory role in the action of DREB2A. The SUMOylation of Lys163, an adjacent lysine to the NRD, interferes with the BPM-DREB2A interaction, stabilizing DREB2A [84]. This SUMOylation process is induced by heat shock, thus tuning the degradation rate of DREB2A in response to abiotic stress.

The same Cul3-BPM1-6 RING E3 complex is also engaged in the degradation of yet another transcription factor of ABA signaling, HOMEOBOX-LEUCINE ZIPPER (HD-ZIP) ATHB6 [56]. In contrast to DREB2A, ATHB6 is a negative regulator of ABA responses, including drought and heat tolerance $[79,80,85]$. BPM silencing, as well as ATHB6 overexpression, leads to an increase in the level of the ATHB6 protein together with the decrease in its ubiquitination status. However, overexpression of BPM6 accelerated the turnover of ATHB6, indicating that BPMs influence ATHB6 stability [56]. Furthermore, BPM silencing results in ABA insensitivity and reduced stomatal closure, leading to increased transpiration and water loss, indicating that BPMs play a positive role in ABA signaling $[56,86]$. Under non-stress conditions, BPMs promote the proteasome-dependent degradation of ATHB6. This turnover of ATHB6 can be inhibited by ABA and may serve to attenuate ABA responses. Furthermore, all six BPM proteins can interact with three different HD-ZIP transcription factors (ATHB5, ATHB6, and ATHB16), implying that this family of E3 ligases may regulate other processes as well [56]. Subsequently, it was reported that BPM1 can interact with another transcription factor, RAV1 (related to ABI3/VP1), which negatively regulates the transcription of ABI3/4/5, unless it is phosphorylated by SnRK2s $[60,61]$. 
The RING-type E3 ligase MYB30-INTERACTING E3 LIGASE 1 (MIEL1) was first described to control the abundance of R2R3-type transcription factor MYB30 that negatively regulates ABA signaling and activates defense and HR responses [59,87]. MIEL1 expression is rapidly downregulated after bacterial infection to allow MYB30 accumulation, thus promoting defense and the hypersensitive response (HR), and the miel1 mutant displays enhanced resistance responses after inoculation with bacteria [59]. In addition to its role in the control of biotic stress, MIEL1 regulates abiotic stress in an ABA-dependent manner by targeting the transcription factor MYB96, which normally promotes the expression of ABI4 [57]. In the absence of ABA, MIEL1 accumulates and promotes the degradation of MYB96 to silence ABA signal transduction, whereas in the presence of the hormone, MIEL1 is degraded by UPS, promoting MYB96 transcriptional activity. According to these findings, MIEL1 may facilitate the ABA-mediated interplay between biotic and abiotic stress [88]. As an added complication, in addition to MIEL1, another RING E3 ligase, RING-H2 FINGER PROTEIN 2B (RHA2B), is also able to bind and promote the degradation of MYB30 in an ABA-dependent manner during drought response [58].

\subsubsection{E3 Indirectly Influencing the Activity of ABA-Responsive Transcription Factors}

In contrast to the E3 ligases described above and defined as negative regulators of ABA signaling, E3 ligase SALT- AND DROUGHT-INDUCED RING FINGER 1 (SDIR1) is genetically characterized as a positive regulator. The sdir1 mutant has reduced sensitivity to $\mathrm{ABA}$ in seed germination and early seedling growth assays and reduced stomatal closure in response to ABA, while overexpression of SDIR1 leads to quite opposite phenotypes $[65,89]$. Furthermore, rice OsSDIR1 is also a functional E3 ligase, and its overexpression leads to markedly increased drought tolerance [90]. SDIR1 interacts with its substrate SDIR1INTERACTING PROTEIN 1 (SDIRIP1) at the endoplasmic reticulum membrane to promote its degradation via the $26 \mathrm{~S}$ proteasome. SDIRIP1 negatively regulates ABI5 expression to impact ABA-mediated seed germination and responses to salt [65]. SDIRIP1 RNAi lines are ABA hypersensitive, suggesting that SDIRIP1 functions as a negative regulator of ABA signaling. Another RING-type E3 ligase has been described to target SDIRIP1 in the cytosol. AtAIRP2 regulated the turnover of SDIRIP1 in cell-free degradation and protoplast co-transfection assays [64]. AtAIRP2 and SDIR1 have combinatory roles in seed germination, as evidenced by reciprocal complementation of the ABA- and salt-insensitive germination phenotypes of sdir1 and atairp2 mutants, respectively. Recently, another link that could promote SDIRIP1 degradation has been described [91]. RESPONSE TO LOW SULFUR 1-4 (LSU1-4), proteins, belonging to a small plant-specific protein family, were identified as important stress-related hubs that bind to SDIRIP1 [91]. LSUs are also able to bind to NBR1, a selective autophagy receptor; therefore, it is tempting to speculate that LSUs might serve as a bridge to facilitate the autophagic degradation of SDIRIP1.

In Arabidopsis, ABA plays a major role in the drought stress response with a welldescribed cis-acting ABA-RESPONSIVE ELEMENT (ABRE) involved in transcriptional activation [92]. Under drought stress conditions, transcription factor $A B F 2$ binds to the ABRE sequence of drought-responsive genes. ABF2 recruits the ADA2B-GCN5 protein complex, in which ADA2B is a transcriptional co-activator protein, while GCN5 acts as a histone acetyltransferase [93,94]. A recent study revealed that ADA2B is targeted for proteasomal degradation by the At1g08710 protein [62]. That F-box protein is localized in the nucleus and forms an SCF complex by interacting with SKP1 and cullin1 proteins. At1g08710 mutant plants present a better survival rate under water deficit conditions and a high accumulation of the ADA2B transcript following ABA treatment. Additionally, transcripts of drought-responsive genes RD22, RD29A, and ABI3 were upregulated under drought stress. These results suggest that F-box protein At1g08710 imparts drought stress tolerance through $\mathrm{ADA} 2 \mathrm{~B}$ degradation. This very recent report proves that $\mathrm{ABF} 2$ is an in vitro ubiquitination substrate of KEG [53]. 


\subsubsection{Links to UPS and Further Layers of Complexity}

UPS selectivity is accomplished not only at the ubiquitination level, but also by the proteasome itself [95]. The $19 \mathrm{~S}$ regulatory particle (RP) of the $26 \mathrm{~S}$ proteasome confers ATP dependence, as well as substrate specificity to the holoenzyme, especially for substrates bearing a poly- $\mathrm{Ub}$ tag. One of the subunits of the RP in Arabidopsis is RPN10. It is essential for the degradation of ABI5 by the proteasome, as evidenced by the increased ABA sensitivity and ABI5 accumulation in the rpn10-1 mutant. This suggests that ABI5 turnover is accomplished through the interaction between ABI5 and RPN10. It is not known whether this interaction is direct or indirect, dependent or independent of the ubiquitination status of ABI5, but it promotes its association with proteasomal proteases. This association may be prevented by the ABA signal which stabilizes ABI5 [96].

The regulation of the stability of ABA-related transcription factors is complex and multilayered. A single E3 ligase such as KEG or BPM can target multiple proteins. Alternatively, a single stress-related protein can be targeted for degradation by multiple E3 ligases. As described, ABI5 abundance is regulated by at least five different E3 ligases, which are used to inhibit its activity under different circumstances [97]. Such a mechanism may rapidly integrate different inputs to control the level of a key transcription factor, leading to the appropriate response. Furthermore, a single $\mathrm{Ub}$ ligase can conjugate $\mathrm{Ub}$ to substrates in a variety of ways (e.g., Lys63- vs. Lys48-linked Ub chains), depending on the signal obtained or the identity of the substrate, leading to different outcomes. An interesting example of such regulation is rice RING E3 ligase IPA1 INTERACTING PROTEIN 1 (IPI1), which ubiquitinates IDEAL PLANT ARCHITECTURE 1 (IPA1) which is involved in plant development [98]. By adding Lys48-linked poly-Ub chains, IPI1 promotes the degradation of IPA1 in panicles, while it stabilizes IPA1 in shoot apexes by adding Lys63-linked poly-Ub chains.

\subsection{Other E3 Ligases Known to Modify ABA-Mediated Responses}

Numerous E3 ligases have been linked to ABA-regulated responses; however, in many cases, their targets have not yet been characterized. These enzymes have been categorized based on their functions as positive and negative modulators of ABA signaling (Table 2 and references therein). In many cases, it is also unclear whether they are present in the same growth conditions, cell types, organs, or developmental stages.

Table 2. E3 ligases with unidentified targets that are known to regulate ABA responses. The original references are provided next to the E3 ligase; however, this table is a compilation of the tables from several earlier reviews $[6,7,12,99,100]$, as well as new data that were not previously reviewed.

\begin{tabular}{ccc}
\hline E3 Family & E3 Ligase [Reference] & Influence on ABA Response/Remarks \\
\hline RING-type & ATL61 [101] & $\begin{array}{c}\text { Positive regulator in the ABA-mediated drought stress } \\
\text { response }\end{array}$ \\
\hline SCF & ARKP1 [102] & $\begin{array}{c}\text { Positive role in ABA signaling network; mutants } \\
\text { displaying reduced ABA-mediated inhibition of seed } \\
\text { germination, root elongation, and water loss rate of } \\
\text { detached leaves }\end{array}$ \\
RING-type & CHYR1/RZP34 [103] & $\begin{array}{c}\text { Promotes ABA-induced stomatal closure, reactive } \\
\text { oxygen species production, and plant drought tolerance; } \\
\text { activity is regulated by SnRK2.6 }\end{array}$ \\
\hline RING-type & SINA2 [104] & $\begin{array}{c}\text { Regulates plant responses to ABA and osmotic stress; } \\
\text { activity is regulated by CDKG1 (cyclin-dependent } \\
\text { kinase G1) }\end{array}$ \\
\hline
\end{tabular}


Table 2. Cont.

\begin{tabular}{|c|c|c|}
\hline E3 Family & E3 Ligase [Reference] & Influence on ABA Response/Remarks \\
\hline RING-type & AtPPRT1 $[105,106]$ & Negative role in ABA and drought stress responses \\
\hline RING-type & AtARRE/ATL27 [107] & Negative regulation in ABA signaling \\
\hline BTB-type & BPH1 [108] & $\begin{array}{l}\text { Negatively involved in ABA-mediated cellular events; } \\
\text { mutation caused delayed seed germination in response } \\
\text { to ABA and resulted in hyper-induction of a large } \\
\text { portion of ABA-inducible genes in response to ABA; } \\
\text { mutants exhibited enhanced stomatal closure under } \\
\text { ABA application and reduced water loss }\end{array}$ \\
\hline RING-type & JUL1 [109] & $\begin{array}{l}\text { ABA-mediated microtubule disorganization; regulates } \\
\text { stomatal closure, and tolerance to drought stress }\end{array}$ \\
\hline RING-type & COP1 [110] & $\begin{array}{l}\text { ABA-mediated microtubule disorganization, stomatal } \\
\text { closure }\end{array}$ \\
\hline RING-type & RDUF1/2 [111] & Negatively regulates ABA signaling \\
\hline RING-type & RHA2a/2b [112,113] & Positively regulates ABA signaling \\
\hline RING-type & AIRP4 [114] & Positively regulates ABA signaling \\
\hline SCF & TLP3/9 [115] & Positively regulates ABA signaling \\
\hline RING-type & ATL43 [116] & Positively regulates ABA signaling \\
\hline RING-type & CER9 [117] & Negatively regulates ABA signaling \\
\hline U-box & PUB9 [118] & Negatively regulates ABA signaling \\
\hline U-box & PUB18/19 [119,120] & $\begin{array}{c}\text { Negatively regulates plant drought response and ABA } \\
\text { signaling }\end{array}$ \\
\hline SCF & DOR [121] & Negatively regulates ABA signaling \\
\hline SCF & EDL3 [122] & $\begin{array}{l}\text { Positive regulator in seed germination and root growth; } \\
\text { positively regulates ABA signaling }\end{array}$ \\
\hline SCF & MAX2 [123] & $\begin{array}{c}\text { Negatively regulates plant drought stress response } \\
\text { through mediating ABA signaling; negatively regulates } \\
\text { ABA signaling }\end{array}$ \\
\hline DDB & DWA3 [124] & $\begin{array}{l}\text { Negatively regulates ABA signaling; mutants exhibited } \\
\text { ABA-hypersensitivity }\end{array}$ \\
\hline U-box & PUB44/SAUL1 [125] & Negatively regulates ABA signaling \\
\hline RING-type & XERICO [126] & $\begin{array}{l}\text { Positively regulates ABA-dependent drought response; } \\
\text { overexpression leads to ABA over-accumulation }\end{array}$ \\
\hline SCF & FOF2 [127] & $\begin{array}{l}\text { Plays an important negative role in ABA-mediated seed } \\
\text { germination and early seedling development, as well as } \\
\text { a positive role in ABA-mediated drought tolerance }\end{array}$ \\
\hline
\end{tabular}

\section{Autophagy as a Cellular Degradation Pathway and a Part of Intracellular Trafficking}

A multistep ubiquitination process resulting in the attachment of Lys48- and Lys63linked poly-Ub tags is used to label proteins degraded by the 26S proteasome (a part of UPS) and via autophagy, respectively. UPS is the key regulator of proteostasis; however, the proteasome and autophagy complement each other in the maintenance of appropriate protein balance in plant development and stress response [5]. Several types of autophagy exist; however, macroautophagy is better described, and it will be called autophagy hereafter. It is characterized by the presence of autophagosomes, double-membrane vesicles surrounding cargos designed for degradation and delivering it to the vacuole, after fusion of the external autophagosomal membrane with the tonoplast $[3,128]$. The selectivity of autophagy is achieved due to the involvement of selective autophagy cargo receptors. 
They recognize cargo and dock to the autophagosomes [129,130]. Autophagy, in contrast to the $26 \mathrm{~S}$ proteasome, can not only degrade proteins and protein aggregates, but also entire organelles or their parts. Therefore, it must be well controlled to avoid excessive degradation of the cellular content. It is negatively regulated by the Target of Rapamycin (TOR) kinase, which, along with its effectors, is active under nutrient-rich conditions when it upregulates cell growth and translation, but it is inactive during nutrient deficiency. The TOR kinase complex is modulated by diverse upstream inputs to phosphorylate different proteins in the nucleus, nucleolus, and cytosol, thus controlling transcription, the cell cycle, rRNA transcription, ribosome biogenesis, translation, and metabolism, which are pivotal to cell proliferation and growth [131,132].

Autophagy is a part of the intracellular vesicular system; therefore, extensive interlinking exists between autophagy and trafficking pathways, and functional endocytic and exocytic pathways are essential for efficient autophagy flux in all eukaryotes [27,133-135]. Autophagy controls degradation, and exocytosis (secretion) is responsible for the transport of cargo to the plasma membrane or extracellular space, while endocytosis transports cargo from the plasma membrane or extracellular space to intracellular organelles [136-138]. Plasma membrane receptors and transporters must be tightly regulated, and part of this control is mediated by their ubiquitination and recruitment to endosomal sorting complexes (ESCORTs) by proteins interacting with ESCORTs, of which, some are capable of Ub-binding $[138,139]$. Actin and microtubule cytoskeletons and their reorganization play an important role in the control of all three processes [140,141].

\section{Role of TOR Kinase, Autophagy, and Intracellular Trafficking in the Control of ABA Signaling}

Various elements of ABA signaling are ubiquitinated and degraded via the $26 \mathrm{~S}$ proteasome $[6,7,100]$. The RPN10 subunit of the $26 \mathrm{~S}$ proteasome controls ABA signaling, as demonstrated by rpn10-1 mutants that were more sensitive to ABA [96]. Interestingly, the same research group determined that RPN10 functions as a selective cargo receptor in proteaphagy (autophagic degradation of $26 \mathrm{~S}$ proteasome) [142]. Data on the interplay of ABA with autophagy are still limited, but growing evidence indicates that they can co-regulate each other. For example, ABA activates autophagy by reducing the ATG4 persulfidation level. The enzymatic activity of ATG4 is reversibly regulated by sulfide, and this regulation effectively controls autophagy flux. ATG4 is necessary for processing newly synthesized ATG8 proteins that can be further lipidated to progress autophagy [143]. However, some data suggest that elevated autophagy might induce ABA responses. For example, the overexpression of banana ATG8f modulated drought stress resistance in Arabidopsis [144], and the overexpression of NBR1 in Arabidopsis resulted in increased ABA signaling [145].

TOR kinase might be involved in the synthesis and/or distribution of ABA [146,147]. Additionally, the reciprocal regulation of ABA signaling and TOR kinase has been reported [148]. In growth-promoting conditions, the phosphorylation of ABA receptors by TOR disrupts their interaction with PP2C phosphatases, which can now interact with SnRK2s. This leads to the inactivation of SnRK2 kinases, thus keeping the ABA response silent. Under stress, ABA-activated SnRK2s induce the ABA response but also inactivate TOR and, in turn, activate autophagy [148]. There are additional indications for TOR-ABA connections. For instance, protein phosphatase 2A (PP2A)-associated proteins TAP46 and TIP41 indirectly influence ABA signaling, while they are also involved in TOR signaling [149-152]. Secondly, transcription factor ABI4, a key player integrating ABA responses, participates in TOR signaling during seed to seedling transition stages [72,153]. Moreover, YET ANOTHER KINASE 1 (YAK1), which was reported to participate in ABA responses, is directly or indirectly repressed by TOR to promote maximal meristem activity and size $[154,155]$. The molecular details of some of these links remain to be characterized. The known elements of ABA-TOR crosstalk are shown in Figure 4A. 


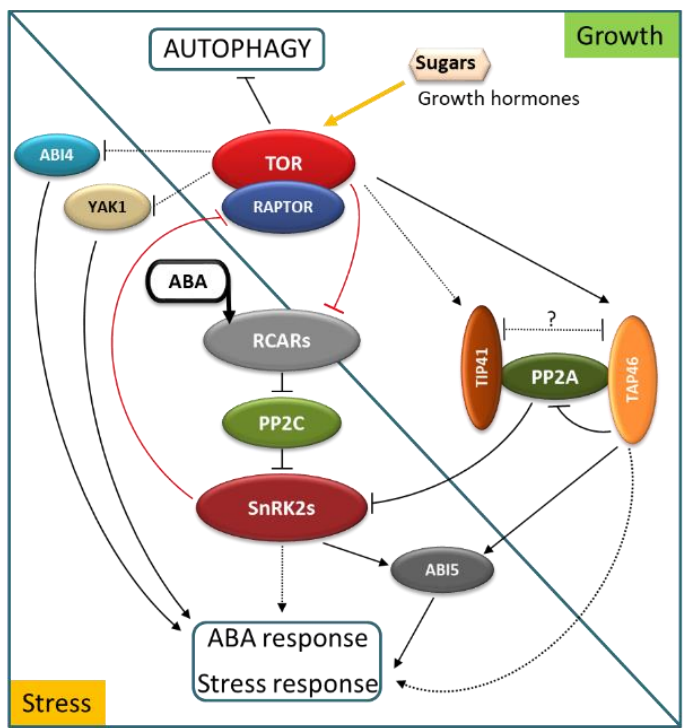

(a)

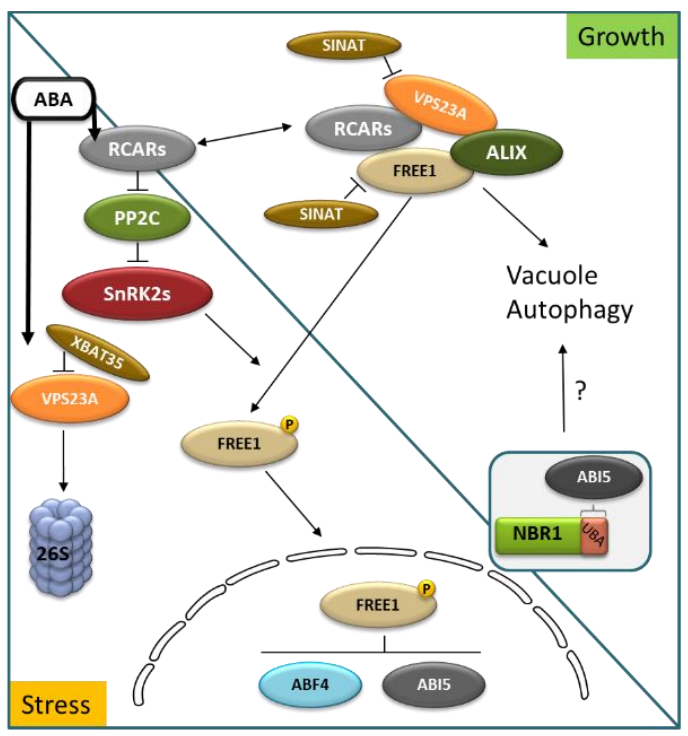

(b)

Figure 4. Links of autophagy with ABA signaling in growth and stress responses. (a) Reciprocal regulations of TOR and ABA signaling pathways. Red lines mark the main regulation circuit, while the other TOR-ABA connections are marked by the black lines. (b) Links of ABA with elements of vesicular transport and an autophagy cargo receptor NBR1. For explanations and references, see the text.

Furthermore, there is an interplay of ABA signaling with endocytosis, exocytosis, the cytoskeleton, and selective targeting of ABA-responsive transcription factors (Figure 4B). The activity of soluble and membrane-located ABA receptors is regulated by proteins linked to endocytosis and autophagy. The connection of some RCARs with the proteins interacting with ESCORT complexes, such as VACUOLAR PROTEIN SORTING23A (VPS23A) [156], FYVE domain protein required for endosomal sorting 1 (FREE1) [157,158], or ALG-2 INTERACTING PROTEIN-X (ALIX) [159], have been revealed. The turnover of ABA receptors is controlled by the targeted ubiquitination of their partners. The XBAT35 E3 ligase is a positive regulator of ABA responses because it accelerates the turnover of VPS23A through the 26S proteasome, thereby reducing vacuolar degradation of RCAR10/PYL4 [160]. In the absence of ABA, the ubiquitinated RCAR10/PYL4 and RCAR11/PYR1 are recognized by VPS23A and FREE1 and targeted for vacuolar degradation. In the presence of ABA, VPS23A and FREE1 are targeted by the SINAT E3 ligase and directed to proteasomal and vacuolar degradation [161]. The termination of ABA responses leads to autophagic clearance of the excess of SINAT-VPS23A and SINAT-FREE1 complexes and the reset of cellular homeostasis.

ABA-mediated stomatal movement is also regulated by the exocyst subunit Exo70B1 [162]. Moreover, ABA mediates microtubule disorganization, which can influence all types of vesicular trafficking $[109,110]$. The links via Rho GTPases/Rho of Plants (ROP), which not only regulate numerous cytoskeleton and vesicular trafficking-based processes but also suppress ABA-induced responses, have also been revealed [163-165].

Interestingly, $\mathrm{ABA}$ also induces Arabidopsis multi-stress regulator tryptophan-rich sensory protein-related (TSPO), which acts as a heme scavenger and binds the excessive or deleterious heme and then is targeted for degradation through autophagy $[163,166]$.

The ABA-autophagy links also take place at the level of ABA-responsive transcription factors. Recently, an interesting possibility for the regulatory circuit between selective autophagy and ABA-responsive transcription factors was suggested by the observation that ABI3, ABI4, and ABI5 interact with selective autophagy cargo receptor NBR1 [145]. Moreover, ABA-activated SnRK2s phosphorylate FREE1, allowing for its nuclear import. In the nucleus, FREE1 interacts with the basic leucine zipper transcription factors ABARESPONSIVE ELEMENTS BINDING FACTOR4 (ABF4) and ABA-INSENSITIVE5 (ABI5) 
to reduce binding to the cis-regulatory sequences of downstream genes and diminish ABA responses [167].

Both ABA signaling and autophagy can also be involved in crosstalk related to ROS (reactive oxygen species) homeostasis. For example, autophagy affects stomatal opening by controlling ROS production in guard cells [168] and regulates glucose-mediated root meristem activity by affecting ROS homeostasis [169]. Conversely, ABI5 regulates ROS during seedling germination by CAT1 catalase activation [170], and ABI4 (acting antagonistically to ETHYLENE-INSENSITIVE3 (EIN3)) regulates ROS accumulation by modulating ascorbic acid biosynthesis [171]. TOR also controls the ROS level by regulating mitochondrial activity [172].

\section{Possible Involvement of Autophagy in ABA Crosstalk with Other Hormones}

ABA is involved in extensive crosstalk with other phytohormones [19,72]. Up to now, autophagy has been suggested to participate in only two of such crosstalk events, ABAcytokinins (CKs) and ABA-brassinosteroids (BRs). It is worth noting that CKs and BRs, similarly to many other hormones, regulate various aspects of plant growth antagonistically to ABA.

ABA-CK crosstalk is particularly apparent in the regulatory loop consisting of type-A and -B response regulators (ARRs) and SnRK2s [173]. Unlike type-B ARRs, which lack a DNA binding domain, type-A ARRs act as negative regulators of cytokinin signaling. Phosphorylation in response to cytokinin stabilizes a subset of the type-A ARRs. Plants modulate responses to $\mathrm{CKs}$, at least in part via the autophagic regulation of type-A ARRs mediated by members of the EXO70D, a subclade of the EXO70 gene family, which act as receptors to recruit type-A ARRs to the autophagosome for subsequent degradation [174]. Additionally, type-A ARRs interact with ABA-responsive transcription factor ABI5 and downregulate ABI5 transcription [175]. The other ABA-responsive transcription factor ABI4 activates ABI4 transcription. Moreover, the interaction of ABI4 and ABI5 with selective autophagy cargo receptor NBR1 with ABI4 and ABI5 suggest that both transcription factors might be degraded via autophagy in an NBR1-dependent manner [145]. A fragment of the CK signaling pathway with ABA-CKs-autophagy interplay is illustrated in Figure 5A.

BR signaling has recently attracted attention [17,176-179]. The cross-regulation of ABA- and BR-signaling pathways is marked in Figure 5B. BRASSINOSTEROID-INSENSITIVE 2 (BIN2) interacts with central components of the ABA signaling pathway, such as bZIP transcription factor ABI5 [180] and protein phosphatase 2C ABI1 [181], and phosphorylates SNF1-related protein kinases SnRK2.2 and SnRK2.3 [182]. Moreover, ABA promotes BR signaling via $A B I 1 / 2$, which, upon binding to BIN2, leads to the reduced phosphorylation of BRI1-EMS-SUPPRESSOR 1 (BES1) [183]. The links to autophagy are apparent on several levels. TOR, a negative regulator of autophagy, positively regulates BR signaling via RPS6 kinase 2 (S6K2), which, in turn, phosphorylates BIN2 [184]. In addition, transcription factor BES1, an important element of BR signaling, is selectively degraded via autophagy after being targeted to autophagosomes by selective autophagy cargo receptor DSK2 [185]. Interesting crosslinks have been observed in tomato, where autophagy-related genes ATG2, ATG6, and NBR1 are induced by BES1, which results in the induction of the autophagy pathway under chilling stress [186]. 


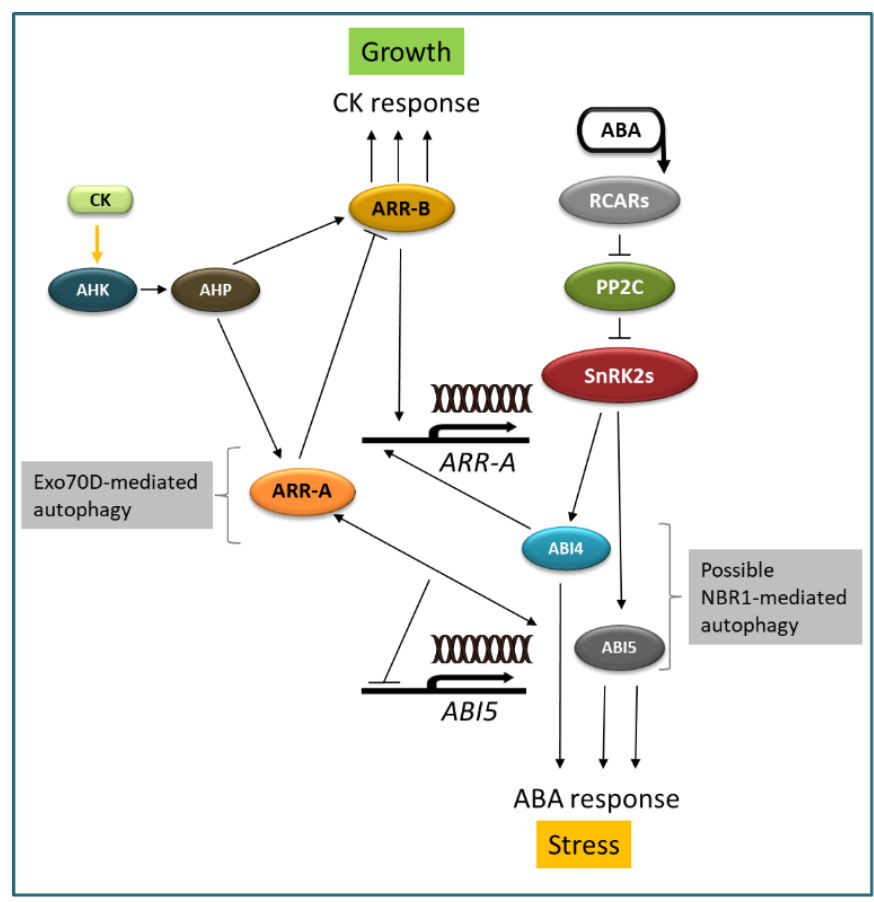

(a)

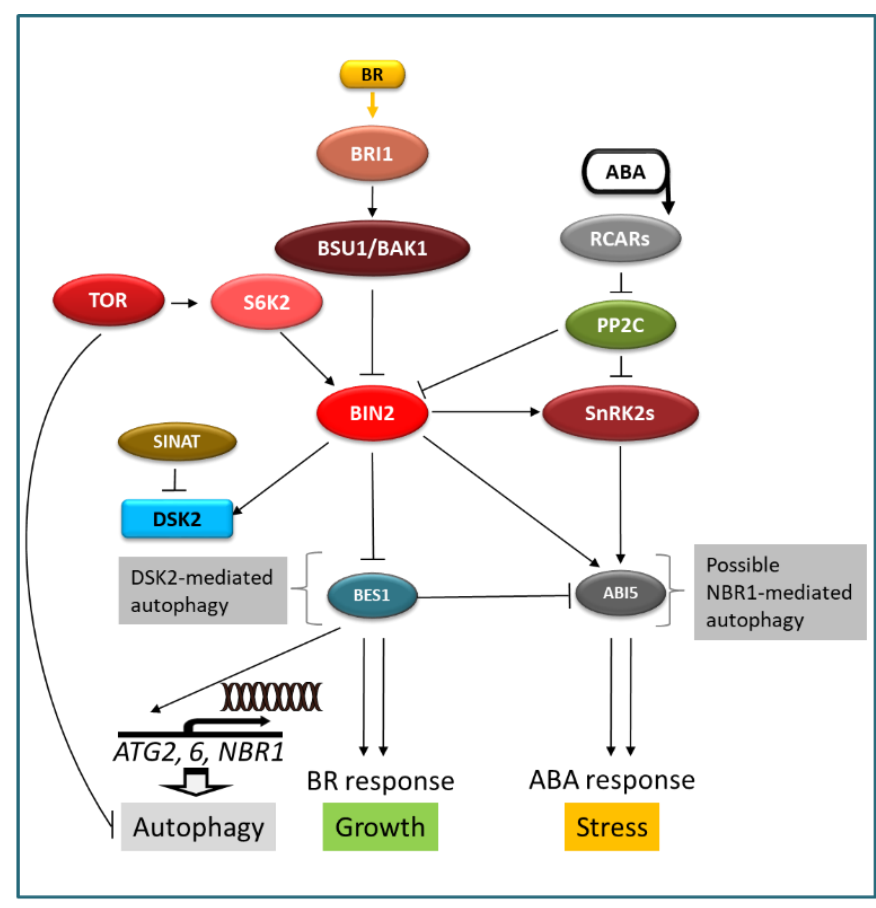

(b)

Figure 5. Interplay of autophagy with ABA-cytokinin crosstalk (a) and ABA-brassinosteroid crosstalk (b). Yellow arrows mark CK and BR signals. Elements of the CK signaling pathway (AHK, histidine kinase receptor(s); AHP, histidine phosphotransfer protein(s)) and BR signaling pathway (BRI1, leucine-rich repeat receptor-like kinase family; BSU1/BAK1, protein kinases; BIN2, GSK3-like kinase; BES1, transcription factor) are marked in panels A and B, respectively. See text for further details.

\section{Closing Remarks}

Perception and signaling of stress-triggering conditions are crucial for plant growth and development. Similarly, the control of ending these signaling events when they are no longer needed and reestablishing homeostasis is important. Ubiquitination, precisely provided by dedicated E3 ligases, is a universal mark for protein degradation. This mark is recognized by two major proteolytic pathways: UPS and autophagy. There are many unanswered questions on how plants coordinate and choose between these different proteolysis pathways to target the same or similar regulatory components. The clue might be in poly-Ub marks that have different architecture. However, what determines how particular E3 ligases structure the $\mathrm{Ub}$ chain is unknown.

During plant growth and development, as well as under stress, different phytohormones are mutually antagonistic and synergistic. Those phytohormones regulate autophagy, and vice versa, autophagy impacts the balance of phytohormones. It was recently discovered that autophagy is involved in the crosstalk of ABA with two hormones, CKs and BRs. However, other hormones are also regulated by ubiquitination and autophagy involvement in the crosstalk of ABA with the other hormones is quite plausible. Although the field is actively investigated, there is still a lot to discover. The future challenge is to identify phytohormone-related proteins that are specific targets of autophagy that are in line with their receptors. This knowledge would extend our understanding about stress regulation and, consequently, provide some new approaches for crop improvement, eventually leading to an increase in stress tolerance and yield.

Funding: Work in the lab is funded by the National Science Center, Poland, grant No. 2018/31/F/NZ1/02234 (SignalOAS).

Conflicts of Interest: The authors declare no conflict of interest. 


\section{References}

1. Orosa, B.; Ustun, S.; Calderon Villalobos, L.I.A.; Genschik, P.; Gibbs, D.; Holdsworth, M.J.; Isono, E.; Lois, M.; Trujillo, M.; Sadanandom, A. Plant proteostasis-Shaping the proteome: A research community aiming to understand molecular mechanisms that control protein abundance. New Phytol. 2020, 227, 1028-1033. [CrossRef]

2. Bence, N.F.; Sampat, R.M.; Kopito, R.R. Impairment of the ubiquitin-proteasome system by protein aggregation. Science 2001, 292, 1552-1555. [CrossRef] [PubMed]

3. Marshall, R.S.; Vierstra, R.D. Autophagy: The master of bulk and selective recycling. Annu. Rev. Plant Biol. 2018, 69, 173-208. [CrossRef]

4. Signorelli, S.; Tarkowski, L.P.; Van den Ende, W.; Bassham, D.C. Linking autophagy to abiotic and biotic stress responses. Trends Plant Sci. 2019, 24, 413-430. [CrossRef] [PubMed]

5. Su, T.; Yang, M.; Wang, P.; Zhao, Y.; Ma, C. Interplay between the ubiquitin proteasome system and ubiquitin-mediated autophagy in plants. Cells 2020, 9, 2219. [CrossRef] [PubMed]

6. Doroodian, P.; Hua, Z. The ubiquitin switch in plant stress response. Plants 2021, 10, 246. [CrossRef] [PubMed]

7. Stone, S.L. Role of the ubiquitin proteasome system in plant response to abiotic stress. Int. Rev. Cell Mol. Biol. 2019, 343, 65-110. [CrossRef]

8. Xu, F.Q.; Xue, H.W. The ubiquitin-proteasome system in plant responses to environments. Plant Cell Environ. 2019, 42, 2931-2944. [CrossRef]

9. Li, Y.; Lin, Y.; Li, X.; Guo, S.; Huang, Y.; Xie, Q. Autophagy dances with phytohormones upon multiple stresses. Plants 2020, 9, 1038. [CrossRef]

10. Finkelstein, R. Abscisic acid synthesis and response. Arab. Book 2013, 11, e0166. [CrossRef]

11. Yoshida, T.; Mogami, J.; Yamaguchi-Shinozaki, K. Omics approaches toward defining the comprehensive abscisic acid signaling network in plants. Plant Cell Physiol. 2015, 56, 1043-1052. [CrossRef]

12. Ali, A.; Pardo, J.M.; Yun, D.J. Desensitization of ABA-signaling: The swing from activation to degradation. Front. Plant Sci. 2020, 11, 379. [CrossRef] [PubMed]

13. Chen, K.; Li, G.J.; Bressan, R.A.; Song, C.P.; Zhu, J.K.; Zhao, Y. Abscisic acid dynamics, signaling, and functions in plants. J. Integr. Plant Biol. 2020, 62, 25-54. [CrossRef]

14. Tal, L.; Gil, M.X.A.; Guercio, A.M.; Shabek, N. Structural aspects of plant hormone signal perception and regulation by ubiquitin ligases. Plant Physiol. 2020, 182, 1537-1544. [CrossRef]

15. Yu, F.; Xie, Q. Non-26S proteasome endomembrane trafficking pathways in ABA signaling. Trends Plant Sci. 2017, 22, 976-985. [CrossRef]

16. Yu, F.F.; Xie, Q. Ubiquitination modification precisely modulates the ABA signaling pathway in plants. Yi Chuan 2017, 39, 692-706 [CrossRef] [PubMed]

17. Bulgakov, V.P.; Avramenko, T.V. Linking brassinosteroid and ABA signaling in the context of stress acclimation. Int. J. Mol. Sci. 2020, 21, 5108. [CrossRef]

18. Hai, N.N.; Chuong, N.N.; Tu, N.H.C.; Kisiala, A.; Hoang, X.L.T.; Thao, N.P. Role and regulation of cytokinins in plant response to drought stress. Plants 2020, 9, 422. [CrossRef] [PubMed]

19. Verma, V.; Ravindran, P.; Kumar, P.P. Plant hormone-mediated regulation of stress responses. BMC Plant Biol. 2016, 16, 86. [CrossRef]

20. Wang, Q.; Yu, F.; Xie, Q. Balancing growth and adaptation to stress: Crosstalk between brassinosteroid and abscisic acid signaling. Plant Cell Environ. 2020, 43, 2325-2335. [CrossRef]

21. Fujii, H.; Zhu, J.K. Arabidopsis mutant deficient in 3 abscisic acid-activated protein kinases reveals critical roles in growth, reproduction, and stress. Proc. Natl. Acad. Sci. USA 2009, 106, 8380-8385. [CrossRef]

22. Soon, F.F.; Ng, L.M.; Zhou, X.E.; West, G.M.; Kovach, A.; Tan, M.H.; Suino-Powell, K.M.; He, Y.; Xu, Y.; Chalmers, M.J.; et al Molecular mimicry regulates ABA signaling by SnRK2 kinases and PP2C phosphatases. Science 2012, 335, 85-88. [CrossRef]

23. Dejonghe, W.; Okamoto, M.; Cutler, S.R. Small molecule probes of ABA biosynthesis and signaling. Plant Cell Physiol. 2018, 59, 1490-1499. [CrossRef]

24. Buetow, L.; Huang, D.T. Structural insights into the catalysis and regulation of E3 ubiquitin ligases. Nat. Rev. Mol. Cell. Biol. 2016, 17, 626-642. [CrossRef]

25. French, M.E.; Koehler, C.F.; Hunter, T. Emerging functions of branched ubiquitin chains. Cell Discov. 2021, 7, 6. [CrossRef] [PubMed]

26. Zientara-Rytter, K.; Subramani, S. The roles of ubiquitin-binding protein shuttles in the degradative fate of ubiquitinated proteins in the ubiquitin-proteasome system and autophagy. Cells 2019, 8, 40. [CrossRef]

27. Zientara-Rytter, K.; Sirko, A. To deliver or to degrade-An interplay of the ubiquitin-proteasome system, autophagy and vesicular transport in plants. FEBS J. 2016, 283, 3534-3555. [CrossRef]

28. Shu, K.; Yang, W. E3 ubiquitin ligases: Ubiquitous actors in plant development and abiotic stress responses. Plant Cell Physiol. 2017, 58, 1461-1476. [CrossRef]

29. Ahn, M.Y.; Oh, T.R.; Seo, D.H.; Kim, J.H.; Cho, N.H.; Kim, W.T. Arabidopsis group XIV ubiquitin-conjugating enzymes AtUBC32, AtUBC33, and AtUBC34 play negative roles in drought stress response. J. Plant Physiol. 2018, 230, 73-79. [CrossRef] 
30. Irigoyen, M.L.; Iniesto, E.; Rodriguez, L.; Puga, M.I.; Yanagawa, Y.; Pick, E.; Strickland, E.; Paz-Ares, J.; Wei, N.; De Jaeger, G.; et al. Targeted degradation of abscisic acid receptors is mediated by the ubiquitin ligase substrate adaptor DDA1 in Arabidopsis. Plant Cell 2014, 26, 712-728. [CrossRef]

31. Li, D.; Zhang, L.; Li, X.; Kong, X.; Wang, X.; Li, Y.; Liu, Z.; Wang, J.; Li, X.; Yang, Y. AtRAE1 is involved in degradation of ABA receptor RCAR1 and negatively regulates ABA signalling in Arabidopsis. Plant Cell Environ. 2018, 41, 231-244. [CrossRef]

32. Zhao, J.; Zhao, L.; Zhang, M.; Zafar, S.A.; Fang, J.; Li, M.; Zhang, W.; Li, X. Arabidopsis E3 ubiquitin ligases PUB22 and PUB23 negatively regulate drought tolerance by targeting ABA receptor PYL9 for degradation. Int. J. Mol. Sci. 2017, 18, 1841. [CrossRef]

33. Li, Y.; Zhang, L.; Li, D.; Liu, Z.; Wang, J.; Li, X.; Yang, Y. The Arabidopsis F-box E3 ligase RIFP1 plays a negative role in abscisic acid signalling by facilitating ABA receptor RCAR3 degradation. Plant Cell Environ. 2016, 39, 571-582. [CrossRef]

34. Bueso, E.; Rodriguez, L.; Lorenzo-Orts, L.; Gonzalez-Guzman, M.; Sayas, E.; Munoz-Bertomeu, J.; Ibanez, C.; Serrano, R.; Rodriguez, P.L. The single-subunit RING-type E3 ubiquitin ligase RSL1 targets PYL4 and PYR1 ABA receptors in plasma membrane to modulate abscisic acid signaling. Plant J. Cell Mol. Biol. 2014, 80, 1057-1071. [CrossRef] [PubMed]

35. Fernandez, M.A.; Belda-Palazon, B.; Julian, J.; Coego, A.; Lozano-Juste, J.; Inigo, S.; Rodriguez, L.; Bueso, E.; Goossens, A.; Rodriguez, P.L. RBR-type E3 ligases and the ubiquitin-conjugating enzyme UBC26 regulate abscisic acid receptor levels and signaling. Plant Physiol. 2020, 182, 1723-1742. [CrossRef]

36. Kong, L.; Cheng, J.; Zhu, Y.; Ding, Y.; Meng, J.; Chen, Z.; Xie, Q.; Guo, Y.; Li, J.; Yang, S.; et al. Degradation of the ABA co-receptor ABI1 by PUB12/13 U-box E3 ligases. Nat. Commun. 2015, 6, 8630. [CrossRef]

37. Julian, J.; Coego, A.; Lozano-Juste, J.; Lechner, E.; Wu, Q.; Zhang, X.; Merilo, E.; Belda-Palazon, B.; Park, S.Y.; Cutler, S.R.; et al. The MATH-BTB BPM3 and BPM5 subunits of Cullin3-RING E3 ubiquitin ligases target PP2CA and other clade A PP2Cs for degradation. Proc. Natl. Acad. Sci. USA 2019, 116, 15725-15734. [CrossRef] [PubMed]

38. Pan, W.; Lin, B.; Yang, X.; Liu, L.; Xia, R.; Li, J.; Wu, Y.; Xie, Q. The UBC27-AIRP3 ubiquitination complex modulates ABA signaling by promoting the degradation of ABI1 in Arabidopsis. Proc. Natl. Acad. Sci. USA 2020, 117, 27694-27702. [CrossRef]

39. Chen, Q.; Bai, L.; Wang, W.; Shi, H.; Ramon Botella, J.; Zhan, Q.; Liu, K.; Yang, H.Q.; Song, C.P. COP1 promotes ABA-induced stomatal closure by modulating the abundance of ABI/HAB and AHG3 phosphatases. New Phytol. 2021, 229, $2035-2049$. [CrossRef]

40. Wu, Q.; Zhang, X.; Peirats-Llobet, M.; Belda-Palazon, B.; Wang, X.; Cui, S.; Yu, X.; Rodriguez, P.L.; An, C. Ubiquitin ligases RGLG1 and RGLG5 regulate abscisic acid signaling by controlling the turnover of phosphatase PP2CA. Plant Cell 2016, 28, $2178-2196$. [CrossRef] [PubMed]

41. Baek, W.; Lim, C.W.; Luan, S.; Lee, S.C. The RING finger E3 ligases PIR1 and PIR2 mediate PP2CA degradation to enhance abscisic acid response in Arabidopsis. Plant J. Cell Mol. Biol. 2019, 100, 473-486. [CrossRef]

42. Cheng, C.; Wang, Z.; Ren, Z.; Zhi, L.; Yao, B.; Su, C.; Liu, L.; Li, X. SCFAtPP2-B11 modulates ABA signaling by facilitating SnRK2.3 degradation in Arabidopsis thaliana. PLoS Genet. 2017, 13, e1006947. [CrossRef]

43. Ali, A.; Kim, J.K.; Jan, M.; Khan, H.A.; Khan, I.U.; Shen, M.; Park, J.; Lim, C.J.; Hussain, S.; Baek, D.; et al. Rheostatic control of ABA signaling through HOS15-mediated OST1 degradation. Mol. Plant 2019, 12, 1447-1462. [CrossRef] [PubMed]

44. Lee, J.H.; Yoon, H.J.; Terzaghi, W.; Martinez, C.; Dai, M.; Li, J.; Byun, M.O.; Deng, X.W. DWA1 and DWA2, two Arabidopsis DWD protein components of CUL4-based E3 ligases, act together as negative regulators in ABA signal transduction. Plant Cell 2010, 22, 1716-1732. [CrossRef] [PubMed]

45. Stone, S.L.; Williams, L.A.; Farmer, L.M.; Vierstra, R.D.; Callis, J. KEEP ON GOING, a RING E3 ligase essential for Arabidopsis growth and development, is involved in abscisic acid signaling. Plant Cell 2006, 18, 3415-3428. [CrossRef]

46. Seo, K.I.; Lee, J.H.; Nezames, C.D.; Zhong, S.; Song, E.; Byun, M.O.; Deng, X.W. ABD1 is an Arabidopsis DCAF substrate receptor for CUL4-DDB1-based E3 ligases that acts as a negative regulator of abscisic acid signaling. Plant Cell 2014, 26, 695-711. [CrossRef]

47. Jin, D.; Wu, M.; Li, B.; Bucker, B.; Keil, P.; Zhang, S.; Li, J.; Kang, D.; Liu, J.; Dong, J.; et al. The COP9 Signalosome regulates seed germination by facilitating protein degradation of RGL2 and ABI5. PLoS Genet. 2018, 14, e1007237. [CrossRef] [PubMed]

48. Kurup, S.; Jones, H.D.; Holdsworth, M.J. Interactions of the developmental regulator ABI3 with proteins identified from developing Arabidopsis seeds. Plant J. Cell Mol. Biol. 2000, 21, 143-155. [CrossRef] [PubMed]

49. Zhang, X.; Garreton, V.; Chua, N.H. The AIP2 E3 ligase acts as a novel negative regulator of ABA signaling by promoting ABI3 degradation. Genes Dev. 2005, 19, 1532-1543. [CrossRef]

50. Xu, X.; Chi, W.; Sun, X.; Feng, P.; Guo, H.; Li, J.; Lin, R.; Lu, C.; Wang, H.; Leister, D.; et al. Convergence of light and chloroplast signals for de-etiolation through ABI4-HY5 and COP1. Nat. Plants 2016, 2, 16066. [CrossRef]

51. Chen, Y.T.; Liu, H.; Stone, S.; Callis, J. ABA and the ubiquitin E3 ligase KEEP ON GOING affect proteolysis of the Arabidopsis. thaliana. transcription factors ABF1 and ABF3. Plant J. Cell Mol. Biol. 2013, 75, 965-976. [CrossRef] [PubMed]

52. Liu, H.; Stone, S.L. Cytoplasmic degradation of the Arabidopsis transcription factor abscisic acid insensitive 5 is mediated by the RING-type E3 ligase KEEP ON GOING. J. Biol. Chem. 2013, 288, 20267-20279. [CrossRef] [PubMed]

53. Linden, K.J.; Chen, Y.-T.; Kyaw, K.; Schultz, B.; Callis, J. Factors that affect protein abundance of the bZIP transcription factor ABRE-BINDING FACTOR 2 (ABF2), a positive regulator of abscisic acid signaling. bioRxiv 2021. [CrossRef]

54. Qin, F.; Sakuma, Y.; Tran, L.S.; Maruyama, K.; Kidokoro, S.; Fujita, Y.; Fujita, M.; Umezawa, T.; Sawano, Y.; Miyazono, K.; et al. Arabidopsis DREB2A-interacting proteins function as RING E3 ligases and negatively regulate plant drought stress-responsive gene expression. Plant Cell 2008, 20, 1693-1707. [CrossRef] [PubMed] 
55. Morimoto, K.; Ohama, N.; Kidokoro, S.; Mizoi, J.; Takahashi, F.; Todaka, D.; Mogami, J.; Sato, H.; Qin, F.; Kim, J.S.; et al. BPM-CUL3 E3 ligase modulates thermotolerance by facilitating negative regulatory domain-mediated degradation of DREB2A in Arabidopsis. Proc. Natl. Acad. Sci. USA 2017, 114, E8528-E8536. [CrossRef]

56. Lechner, E.; Leonhardt, N.; Eisler, H.; Parmentier, Y.; Alioua, M.; Jacquet, H.; Leung, J.; Genschik, P. MATH/BTB CRL3 receptors target the homeodomain-leucine zipper ATHB6 to modulate abscisic acid signaling. Dev. Cell 2011, 21, 1116-1128. [CrossRef]

57. Lee, H.G.; Seo, P.J. The Arabidopsis MIEL1 E3 ligase negatively regulates ABA signalling by promoting protein turnover of MYB96. Nat. Commun. 2016, 7, 12525. [CrossRef]

58. Zheng, Y.; Chen, Z.; Ma, L.; Liao, C. The ubiquitin E3 ligase RHA2b promotes degradation of MYB30 in abscisic acid signaling. Plant Physiol. 2018, 178, 428-440. [CrossRef]

59. Marino, D.; Froidure, S.; Canonne, J.; Ben Khaled, S.; Khafif, M.; Pouzet, C.; Jauneau, A.; Roby, D.; Rivas, S. Arabidopsis ubiquitin ligase MIEL1 mediates degradation of the transcription factor MYB30 weakening plant defence. Nat. Commun. 2013, 4, 1476. [CrossRef] [PubMed]

60. Chen, L.; Lee, J.H.; Weber, H.; Tohge, T.; Witt, S.; Roje, S.; Fernie, A.R.; Hellmann, H. Arabidopsis BPM proteins function as substrate adaptors to a cullin3-based E3 ligase to affect fatty acid metabolism in plants. Plant Cell 2013, 25, 2253-2264. [CrossRef]

61. Feng, C.Z.; Chen, Y.; Wang, C.; Kong, Y.H.; Wu, W.H.; Chen, Y.F. Arabidopsis RAV1 transcription factor, phosphorylated by SnRK2 kinases, regulates the expression of ABI3, ABI4, and ABI5 during seed germination and early seedling development. Plant J. Cell Mol. Biol. 2014, 80, 654-668. [CrossRef]

62. Rao, V.; Virupapuram, V. Arabidopsis F-box protein At1g08710 interacts with transcriptional protein ADA2b and imparts drought stress tolerance by negatively regulating seedling growth. Biochem. Biophys. Res. Commun. 2021, 536, 45-51. [CrossRef]

63. Cho, S.K.; Ryu, M.Y.; Seo, D.H.; Kang, B.G.; Kim, W.T. The Arabidopsis RING E3 ubiquitin ligase AtAIRP2 plays combinatory roles with AtAIRP1 in abscisic acid-mediated drought stress responses. Plant Physiol. 2011, 157, 2240-2257. [CrossRef] [PubMed]

64. Oh, T.R.; Kim, J.H.; Cho, S.K.; Ryu, M.Y.; Yang, S.W.; Kim, W.T. AtAIRP2 E3 ligase affects ABA and high-salinity responses by stimulating its ATP1/SDIRIP1 substrate turnover. Plant Physiol. 2017, 174, 2515-2531. [CrossRef] [PubMed]

65. Zhang, H.; Cui, F.; Wu, Y.; Lou, L.; Liu, L.; Tian, M.; Ning, Y.; Shu, K.; Tang, S.; Xie, Q. The RING finger ubiquitin E3 ligase SDIR1 targets SDIR1-INTERACTING PROTEIN1 for degradation to modulate the salt stress response and ABA signaling in Arabidopsis. Plant Cell 2015, 27, 214-227. [CrossRef]

66. Li, Q.; Serio, R.J.; Schofield, A.; Liu, H.; Rasmussen, S.R.; Hofius, D.; Stone, S.L. Arabidopsis RING-type E3 ubiquitin ligase XBAT35.2 promotes proteasome-dependent degradation of ACD11 to attenuate abiotic stress tolerance. Plant J. Cell Mol. Biol. 2020, 104, 1712-1723. [CrossRef]

67. Kim, J.H.; Kim, W.T. The Arabidopsis RING E3 ubiquitin ligase AtAIRP3/LOG2 participates in positive regulation of high-salt and drought stress responses. Plant Physiol. 2013, 162, 1733-1749. [CrossRef]

68. Lyzenga, W.J.; Liu, H.; Schofield, A.; Muise-Hennessey, A.; Stone, S.L. Arabidopsis CIPK26 interacts with KEG, components of the ABA signalling network and is degraded by the ubiquitin-proteasome system. J. Exp. Bot. 2013, 64, 2779-2791. [CrossRef]

69. Lyzenga, W.J.; Sullivan, V.; Liu, H.; Stone, S.L. The kinase activity of Calcineurin B-like Interacting Protein Kinase 26 (CIPK26) influences its own stability and that of the ABA-regulated ubiquitin ligase, Keep on Going (KEG). Front. Plant Sci. 2017, 8, 502. [CrossRef] [PubMed]

70. Luo, J.; Shen, G.; Yan, J.; He, C.; Zhang, H. AtCHIP functions as an E3 ubiquitin ligase of protein phosphatase 2A subunits and alters plant response to abscisic acid treatment. Plant J. Cell Mol. Biol. 2006, 46, 649-657. [CrossRef]

71. Park, G.G.; Park, J.J.; Yoon, J.; Yu, S.N.; An, G. A RING finger E3 ligase gene, Oryza sativa. Delayed Seed Germination 1 (OsDSG1), controls seed germination and stress responses in rice. Plant Mol. Biol. 2010, 74, 467-478. [CrossRef]

72. Chandrasekaran, U.; Luo, X.; Zhou, W.; Shu, K. Multifaceted signaling networks mediated by Abscisic Acid Insensitive 4. Plant Commun. 2020, 1, 100040. [CrossRef] [PubMed]

73. Finkelstein, R.; Lynch, T.; Reeves, W.; Petitfils, M.; Mostachetti, M. Accumulation of the transcription factor ABA-insensitive (ABI)4 is tightly regulated post-transcriptionally. J. Exp. Bot. 2011, 62, 3971-3979. [CrossRef] [PubMed]

74. Hua, Z.; Vierstra, R.D. The cullin-RING ubiquitin-protein ligases. Annu. Rev. Plant Biol. 2011, 62, 299-334. [CrossRef] [PubMed]

75. Lopez-Molina, L.; Mongrand, S.; Kinoshita, N.; Chua, N.H. AFP is a novel negative regulator of ABA signaling that promotes ABI5 protein degradation. Genes Dev. 2003, 17, 410-418. [CrossRef] [PubMed]

76. Tang, N.; Ma, S.; Zong, W.; Yang, N.; Lv, Y.; Yan, C.; Guo, Z.; Li, J.; Li, X.; Xiang, Y.; et al. MODD mediates deactivation and degradation of OsbZIP46 to negatively regulate ABA signaling and drought resistance in rice. Plant Cell 2016, 28, 2161-2177. [CrossRef]

77. Lopez-Molina, L.; Mongrand, S.; Chua, N.H. A postgermination developmental arrest checkpoint is mediated by abscisic acid and requires the ABI5 transcription factor in Arabidopsis. Proc. Natl. Acad. Sci. USA 2001, 98, 4782-4787. [CrossRef]

78. Miura, K.; Lee, J.; Jin, J.B.; Yoo, C.Y.; Miura, T.; Hasegawa, P.M. Sumoylation of ABI5 by the Arabidopsis SUMO E3 ligase SIZ1 negatively regulates abscisic acid signaling. Proc. Natl. Acad. Sci. USA 2009, 106, 5418-5423. [CrossRef] [PubMed]

79. Sakuma, Y.; Maruyama, K.; Osakabe, Y.; Qin, F.; Seki, M.; Shinozaki, K.; Yamaguchi-Shinozaki, K. Functional analysis of an Arabidopsis transcription factor, DREB2A, involved in drought-responsive gene expression. Plant Cell 2006, 18, 1292-1309. [CrossRef] 
80. Sakuma, Y.; Maruyama, K.; Qin, F.; Osakabe, Y.; Shinozaki, K.; Yamaguchi-Shinozaki, K. Dual function of an Arabidopsis transcription factor DREB2A in water-stress-responsive and heat-stress-responsive gene expression. Proc. Natl. Acad. Sci. USA 2006, 103, 18822-18827. [CrossRef]

81. Morimoto, K.; Mizoi, J.; Qin, F.; Kim, J.S.; Sato, H.; Osakabe, Y.; Shinozaki, K.; Yamaguchi-Shinozaki, K. Stabilization of Arabidopsis DREB2A is required but not sufficient for the induction of target genes under conditions of stress. PLoS ONE 2013, 8, e80457. [CrossRef]

82. Zhang, N.; Yin, Y.; Liu, X.; Tong, S.; Xing, J.; Zhang, Y.; Pudake, R.N.; Izquierdo, E.M.; Peng, H.; Xin, M.; et al. The E3 ligase TaSAP5 alters drought stress responses by promoting the degradation of DRIP proteins. Plant Physiol. 2017, 175, 1878-1892. [CrossRef]

83. Choi, H.; Han, S.; Shin, D.; Lee, S. Polyubiquitin recognition by AtSAP5, an A20-type zinc finger containing protein from Arabidopsis thaliana. Biochem. Biophys. Res. Commun. 2012, 419, 436-440. [CrossRef]

84. Wang, F.; Liu, Y.; Shi, Y.; Han, D.; Wu, Y.; Ye, W.; Yang, H.; Li, G.; Cui, F.; Wan, S.; et al. SUMOylation stabilizes the transcription factor DREB2A to improve plant thermotolerance. Plant Physiol. 2020, 183, 41-50. [CrossRef]

85. Himmelbach, A.; Hoffmann, T.; Leube, M.; Hohener, B.; Grill, E. Homeodomain protein ATHB6 is a target of the protein phosphatase ABI1 and regulates hormone responses in Arabidopsis. EMBO J. 2002, 21, 3029-3038. [CrossRef] [PubMed]

86. Johannesson, H.; Wang, Y.; Hanson, J.; Engstrom, P. The Arabidopsis thaliana homeobox gene ATHB5 is a potential regulator of abscisic acid responsiveness in developing seedlings. Plant Mol. Biol. 2003, 51, 719-729. [CrossRef]

87. Zheng, Y.; Schumaker, K.S.; Guo, Y. Sumoylation of transcription factor MYB30 by the small ubiquitin-like modifier E3 ligase SIZ1 mediates abscisic acid response in Arabidopsis thaliana. Proc. Natl. Acad. Sci. USA 2012, 109, 12822-12827. [CrossRef] [PubMed]

88. Lee, S.C.; Luan, S. ABA signal transduction at the crossroad of biotic and abiotic stress responses. Plant Cell Environ. 2012, 35, 53-60. [CrossRef] [PubMed]

89. Zhang, Y.; Yang, C.; Li, Y.; Zheng, N.; Chen, H.; Zhao, Q.; Gao, T.; Guo, H.; Xie, Q. SDIR1 is a RING finger E3 ligase that positively regulates stress-responsive abscisic acid signaling in Arabidopsis. Plant Cell 2007, 19, 1912-1929. [CrossRef] [PubMed]

90. Gao, T.; Wu, Y.; Zhang, Y.; Liu, L.; Ning, Y.; Wang, D.; Tong, H.; Chen, S.; Chu, C.; Xie, Q. OsSDIR1 overexpression greatly improves drought tolerance in transgenic rice. Plant Mol. Biol. 2011, 76, 145-156. [CrossRef] [PubMed]

91. Niemiro, A.; Cysewski, D.; Brzywczy, J.; Wawrzynska, A.; Sienko, M.; Poznanski, J.; Sirko, A. Similar but not identical-binding properties of LSU (Response to Low Sulfur) proteins from Arabidopsis thaliana. Front. Plant Sci. 2020, 11, 1246. [CrossRef] [PubMed]

92. Gomez-Porras, J.L.; Riano-Pachon, D.M.; Dreyer, I.; Mayer, J.E.; Mueller-Roeber, B. Genome-wide analysis of ABA-responsive elements ABRE and CE3 reveals divergent patterns in Arabidopsis and rice. BMC Genom. 2007, 8, 260. [CrossRef] [PubMed]

93. Stockinger, E.J.; Mao, Y.; Regier, M.K.; Triezenberg, S.J.; Thomashow, M.F. Transcriptional adaptor and histone acetyltransferase proteins in Arabidopsis and their interactions with CBF1, a transcriptional activator involved in cold-regulated gene expression. Nucleic Acids Res. 2001, 29, 1524-1533. [CrossRef] [PubMed]

94. Vlachonasios, K.E.; Thomashow, M.F.; Triezenberg, S.J. Disruption mutations of ADA2b and GCN5 transcriptional adaptor genes dramatically affect Arabidopsis growth, development, and gene expression. Plant Cell 2003, 15, 626-638. [CrossRef] [PubMed]

95. Smalle, J.; Vierstra, R.D. The ubiquitin $26 \mathrm{~S}$ proteasome proteolytic pathway. Annu. Rev. Plant Biol. 2004, 55, 555-590. [CrossRef] [PubMed]

96. Smalle, J.; Kurepa, J.; Yang, P.; Emborg, T.J.; Babiychuk, E.; Kushnir, S.; Vierstra, R.D. The pleiotropic role of the $26 \mathrm{~S}$ proteasome subunit RPN10 in Arabidopsis growth and development supports a substrate-specific function in abscisic acid signaling. Plant Cell 2003, 15, 965-980. [CrossRef]

97. Liu, H.; Stone, S.L. Regulation of ABI5 turnover by reversible post-translational modifications. Plant Signal. Behav. 2014, 9, e27577. [CrossRef]

98. Wang, J.; Yu, H.; Xiong, G.; Lu, Z.; Jiao, Y.; Meng, X.; Liu, G.; Chen, X.; Wang, Y.; Li, J. Tissue-specific ubiquitination by IPA1 INTERACTING PROTEIN1 modulates IPA1 protein levels to regulate plant architecture in rice. Plant Cell 2017, $29,697-707$. [CrossRef]

99. Yang, W.; Zhang, W.; Wang, X. Post-translational control of ABA signalling: The roles of protein phosphorylation and ubiquitination. Plant Biotechnol. J. 2017, 15, 4-14. [CrossRef]

100. Yu, F.; Wu, Y.; Xie, Q. Ubiquitin-proteasome system in ABA signaling: From perception to action. Mol. Plant 2016, 9, 21-33. [CrossRef]

101. Yang, R.; Wang, T.; Shi, W.; Li, S.; Liu, Z.; Wang, J.; Yang, Y. E3 ubiquitin ligase ATL61 acts as a positive regulator in abscisic acid mediated drought response in Arabidopsis. Biochem. Biophys. Res. Commun. 2020, 528, 292-298. [CrossRef]

102. Li, Y.; Liu, Z.; Wang, J.; Li, X.; Yang, Y. The Arabidopsis Kelch repeat F-box E3 ligase ARKP1 plays a positive role for the regulation of abscisic acid signaling. Plant Mol. Biol. Rep. 2016, 34, 582-591. [CrossRef]

103. Ding, S.; Zhang, B.; Qin, F. Arabidopsis RZFP34/CHYR1, a ubiquitin E3 ligase, regulates stomatal movement and drought tolerance via SnRK2.6-mediated phosphorylation. Plant Cell 2015, 27, 3228-3244. [CrossRef] [PubMed]

104. Chen, Y.; Fokar, M.; Kang, M.; Chen, N.; Allen, R.D.; Chen, Y. Phosphorylation of Arabidopsis SINA2 by CDKG1 affects its ubiquitin ligase activity. BMC Plant Biol. 2018, 18, 147. [CrossRef] [PubMed]

105. Liu, Y.; Pei, L.; Xiao, S.; Peng, L.; Liu, Z.; Li, X.; Yang, Y.; Wang, J. AtPPRT1 negatively regulates salt stress response in Arabidopsis seedlings. Plant Signal. Behav. 2020, 15, 1732103. [CrossRef] 
106. Pei, L.; Peng, L.; Wan, X.; Xiong, J.; Liu, Z.; Li, X.; Yang, Y.; Wang, J. Expression pattern and function analysis of AtPPRT1, a novel negative regulator in ABA and drought stress responses in Arabidopsis. Int. J. Mol. Sci. 2019, 20, 394. [CrossRef] [PubMed]

107. Wang, B.; Li, C.; Kong, X.; Li, Y.; Liu, Z.; Wang, J.; Li, X.; Yang, Y. AtARRE, an E3 ubiquitin ligase, negatively regulates ABA signaling in Arabidopsis thaliana. Plant Cell Rep. 2018, 37, 1269-1278. [CrossRef]

108. Woo, O.G.; Kim, S.H.; Cho, S.K.; Kim, S.H.; Lee, H.N.; Chung, T.; Yang, S.W.; Lee, J.H. BPH1, a novel substrate receptor of CRL3, plays a repressive role in ABA signal transduction. Plant Mol. Biol. 2018, 96, 593-606. [CrossRef] [PubMed]

109. Yu, S.G.; Kim, J.H.; Cho, N.H.; Oh, T.R.; Kim, W.T. Arabidopsis RING E3 ubiquitin ligase JUL1 participates in ABA-mediated microtubule depolymerization, stomatal closure, and tolerance response to drought stress. Plant J. Cell Mol. Biol. 2020, 103, 824-842. [CrossRef]

110. Khanna, R.; Li, J.; Tseng, T.S.; Schroeder, J.I.; Ehrhardt, D.W.; Briggs, W.R. COP1 jointly modulates cytoskeletal processes and electrophysiological responses required for stomatal closure. Mol. Plant 2014, 7, 1441-1454. [CrossRef]

111. Kim, S.J.; Ryu, M.Y.; Kim, W.T. Suppression of Arabidopsis RING-DUF1117 E3 ubiquitin ligases, AtRDUF1 and AtRDUF2, reduces tolerance to ABA-mediated drought stress. Biochem. Biophys. Res. Commun. 2012, 420, 141-147. [CrossRef]

112. Bu, Q.; Li, H.; Zhao, Q.; Jiang, H.; Zhai, Q.; Zhang, J.; Wu, X.; Sun, J.; Xie, Q.; Wang, D.; et al. The Arabidopsis RING finger E3 ligase RHA2a is a novel positive regulator of abscisic acid signaling during seed germination and early seedling development. Plant Physiol. 2009, 150, 463-481. [CrossRef] [PubMed]

113. Li, H.; Jiang, H.; Bu, Q.; Zhao, Q.; Sun, J.; Xie, Q.; Li, C. The Arabidopsis RING finger E3 ligase RHA2b acts additively with RHA2a in regulating abscisic acid signaling and drought response. Plant Physiol. 2011, 156, 550-563. [CrossRef] [PubMed]

114. Yang, L.; Liu, Q.; Liu, Z.; Yang, H.; Wang, J.; Li, X.; Yang, Y. Arabidopsis C3HC4-RING finger E3 ubiquitin ligase AtAIRP4 positively regulates stress-responsive abscisic acid signaling. J. Integr. Plant Biol. 2016, 58, 67-80. [CrossRef] [PubMed]

115. Bao, Y.; Song, W.M.; Jin, Y.L.; Jiang, C.M.; Yang, Y.; Li, B.; Huang, W.J.; Liu, H.; Zhang, H.X. Characterization of Arabidopsis Tubby-like proteins and redundant function of AtTLP3 and AtTLP9 in plant response to ABA and osmotic stress. Plant Mol. Biol. 2014, 86, 471-483. [CrossRef] [PubMed]

116. Serrano, M.; Parra, S.; Alcaraz, L.D.; Guzman, P. The ATL gene family from Arabidopsis thaliana and Oryza sativa comprises a large number of putative ubiquitin ligases of the RING-H2 type. J. Mol. Evol. 2006, 62, 434-445. [CrossRef] [PubMed]

117. Zhao, H.; Zhang, H.; Cui, P.; Ding, F.; Wang, G.; Li, R.; Jenks, M.A.; Lu, S.; Xiong, L. The putative E3 ubiquitin ligase ECERIFERUM9 regulates abscisic acid biosynthesis and response during seed germination and postgermination growth in Arabidopsis. Plant Physiol. 2014, 165, 1255-1268. [CrossRef] [PubMed]

118. Samuel, M.A.; Mudgil, Y.; Salt, J.N.; Delmas, F.; Ramachandran, S.; Chilelli, A.; Goring, D.R. Interactions between the S-domain receptor kinases and AtPUB-ARM E3 ubiquitin ligases suggest a conserved signaling pathway in Arabidopsis. Plant Physiol. 2008, 147, 2084-2095. [CrossRef]

119. Bergler, J.; Hoth, S. Plant U-box armadillo repeat proteins AtPUB18 and AtPUB19 are involved in salt inhibition of germination in Arabidopsis. Plant Biol. 2011, 13, 725-730. [CrossRef]

120. Liu, Y.C.; Wu, Y.R.; Huang, X.H.; Sun, J.; Xie, Q. AtPUB19, a U-box E3 ubiquitin ligase, negatively regulates abscisic acid and drought responses in Arabidopsis thaliana. Mol. Plant 2011, 4, 938-946. [CrossRef]

121. Zhang, Y.; Xu, W.; Li, Z.; Deng, X.W.; Wu, W.; Xue, Y. F-box protein DOR functions as a novel inhibitory factor for abscisic acid-induced stomatal closure under drought stress in Arabidopsis. Plant Physiol. 2008, 148, 2121-2133. [CrossRef]

122. Koops, P.; Pelser, S.; Ignatz, M.; Klose, C.; Marrocco-Selden, K.; Kretsch, T. EDL3 is an F-box protein involved in the regulation of abscisic acid signalling in Arabidopsis thaliana. J. Exp. Bot. 2011, 62, 5547-5560. [CrossRef]

123. Bu, Q.; Lv, T.; Shen, H.; Luong, P.; Wang, J.; Wang, Z.; Huang, Z.; Xiao, L.; Engineer, C.; Kim, T.H.; et al. Regulation of drought tolerance by the F-box protein MAX2 in Arabidopsis. Plant Physiol. 2014, 164, 424-439. [CrossRef]

124. Lee, J.H.; Terzaghi, W.; Deng, X.W. DWA3, an Arabidopsis DWD protein, acts as a negative regulator in ABA signal transduction. Plant Sci. 2011, 180, 352-357. [CrossRef] [PubMed]

125. Salt, J.N.; Yoshioka, K.; Moeder, W.; Goring, D.R. Altered germination and subcellular localization patterns for PUB44/SAUL1 in response to stress and phytohormone treatments. PLOS ONE 2011, 6, e21321. [CrossRef]

126. Ko, J.H.; Yang, S.H.; Han, K.H. Upregulation of an Arabidopsis RING-H2 gene, XERICO, confers drought tolerance through increased abscisic acid biosynthesis. Plant J. Cell Mol. Biol. 2006, 47, 343-355. [CrossRef] [PubMed]

127. Qu, L.; Sun, M.; Li, X.; He, R.; Zhong, M.; Luo, D.; Liu, X.; Zhao, X. The Arabidopsis F-box protein FOF2 regulates ABA-mediated seed germination and drought tolerance. Plant Sci. 2020, 301, 110643. [CrossRef]

128. Su, T.; Li, X.; Yang, M.; Shao, Q.; Zhao, Y.; Ma, C.; Wang, P. Autophagy: An intracellular degradation pathway regulating plant survival and stress response. Front. Plant Sci. 2020, 11, 164. [CrossRef] [PubMed]

129. Lin, Y.; Guo, R.; Ji, C.; Zhou, J.; Jiang, L. New insights into AtNBR1 as a selective autophagy cargo receptor in Arabidopsis. Plant Signal. Behav. 2021, 16, 1839226. [CrossRef] [PubMed]

130. Luo, S.; Li, X.; Zhang, Y.; Fu, Y.; Fan, B.; Zhu, C.; Chen, Z. Cargo recognition and function of selective autophagy receptors in plants. Int. J. Mol. Sci. 2021, 22, 1013. [CrossRef] [PubMed]

131. Ingargiola, C.; Turqueto Duarte, G.; Robaglia, C.; Leprince, A.S.; Meyer, C. The plant Target of Rapamycin: A conduc TOR of nutrition and metabolism in photosynthetic organisms. Genes 2020, 11, 1285. [CrossRef] [PubMed]

132. Xiong, Y.; Sheen, J. Novel links in the plant TOR kinase signaling network. Curr. Opin. Plant Biol. 2015, 28, 83-91. [CrossRef] [PubMed] 
133. Papandreou, M.E.; Tavernarakis, N. Crosstalk between endo/exocytosis and autophagy in health and disease. Biotechnol. J. 2020, 15, e1900267. [CrossRef]

134. Pecenkova, T.; Markovic, V.; Sabol, P.; Kulich, I.; Zarsky, V. Exocyst and autophagy-related membrane trafficking in plants. J. Exp. Bot. 2017, 69, 47-57. [CrossRef] [PubMed]

135. Saeed, B.; Brillada, C.; Trujillo, M. Dissecting the plant exocyst. Curr. Opin. Plant Biol. 2019, 52, 69-76. [CrossRef] [PubMed]

136. Elliott, L.; Moore, I.; Kirchhelle, C. Spatio-temporal control of post-Golgi exocytic trafficking in plants. J. Cell Sci. $2020,133$. [CrossRef]

137. Kanazawa, T.; Ueda, T. Exocytic trafficking pathways in plants: Why and how they are redirected. New Phytol. 2017, 215, 952-957. [CrossRef]

138. Mosesso, N.; Nagel, M.K.; Isono, E. Ubiquitin recognition in endocytic trafficking—With or without ESCRT-0. J. Cell Sci. 2019, 132. [CrossRef] [PubMed]

139. Gao, C.; Zhuang, X.; Shen, J.; Jiang, L. Plant ESCRT complexes: Moving beyond endosomal sorting. Trends. Plant Sci. 2017, 22, 986-998. [CrossRef]

140. Geitmann, A.; Nebenfuhr, A. Navigating the plant cell: Intracellular transport logistics in the green kingdom. Mol. Biol. Cell 2015, 26, 3373-3378. [CrossRef]

141. Koppers, M.; Ozkan, N.; Farias, G.G. Complex interactions between membrane-bound organelles, biomolecular condensates and the cytoskeleton. Front. Cell Dev. Biol. 2020, 8, 618733. [CrossRef]

142. Marshall, R.S.; Li, F.; Gemperline, D.C.; Book, A.J.; Vierstra, R.D. Autophagic degradation of the $26 \mathrm{~S}$ proteasome is mediated by the dual ATG8/ubiquitin receptor RPN10 in Arabidopsis. Mol. Cell 2015, 58, 1053-1066. [CrossRef]

143. Laureano-Marin, A.M.; Aroca, A.; Perez-Perez, M.E.; Yruela, I.; Jurado-Flores, A.; Moreno, I.; Crespo, J.L.; Romero, L.C.; Gotor, C. Abscisic acid-triggered persulfidation of the Cys protease ATG4 mediates regulation of autophagy by sulfide. Plant Cell 2020, 32, 3902-3920. [CrossRef]

144. Li, B.; Liu, G.; Wang, Y.; Wei, Y.; Shi, H. Overexpression of banana ATG8f modulates drought stress resistance in Arabidopsis. Biomolecules 2019, 9, 814. [CrossRef] [PubMed]

145. Tarnowski, L.; Rodriguez, M.C.; Brzywczy, J.; Piecho-Kabacik, M.; Krckova, Z.; Martinec, J.; Wawrzynska, A.; Sirko, A. A selective autophagy cargo receptor NBR1 modulates abscisic acid signalling in Arabidopsis thaliana. Sci. Rep. 2020, 10, 7778. [CrossRef] [PubMed]

146. Kravchenko, A.; Citerne, S.; Jehanno, I.; Bersimbaev, R.I.; Veit, B.; Meyer, C.; Leprince, A.S. Mutations in the Arabidopsis Lst8 and Raptor genes encoding partners of the TOR complex, or inhibition of TOR activity decrease abscisic acid (ABA) synthesis. Biochem. Biophys. Res. Commun. 2015, 467, 992-997. [CrossRef]

147. Salem, M.A.; Li, Y.; Wiszniewski, A.; Giavalisco, P. Regulatory-associated protein of TOR (RAPTOR) alters the hormonal and metabolic composition of Arabidopsis seeds, controlling seed morphology, viability and germination potential. Plant J. Cell Mol. Biol. 2017, 92, 525-545. [CrossRef]

148. Wang, P.; Zhao, Y.; Li, Z.; Hsu, C.C.; Liu, X.; Fu, L.; Hou, Y.J.; Du, Y.; Xie, S.; Zhang, C.; et al. Reciprocal regulation of the TOR kinase and ABA receptor balances plant growth and stress response. Mol. Cell 2018, 69, 100-112.e106. [CrossRef] [PubMed]

149. Hu, R.; Zhu, Y.; Shen, G.; Zhang, H. TAP46 plays a positive role in the ABSCISIC ACID INSENSITIVE5-regulated gene expression in Arabidopsis. Plant Physiol. 2014, 164, 721-734. [CrossRef] [PubMed]

150. Punzo, P.; Ruggiero, A.; Grillo, S.; Batelli, G. TIP41 network analysis and mutant phenotypes predict interactions between the TOR and ABA pathways. Plant Signal. Behav. 2018, 13, e1537698. [CrossRef]

151. Punzo, P.; Ruggiero, A.; Possenti, M.; Nurcato, R.; Costa, A.; Morelli, G.; Grillo, S.; Batelli, G. The PP2A-interactor TIP41 modulates ABA responses in Arabidopsis thaliana. Plant J. Cell Mol. Biol. 2018, 94, 991-1009. [CrossRef]

152. Waadt, R.; Manalansan, B.; Rauniyar, N.; Munemasa, S.; Booker, M.A.; Brandt, B.; Waadt, C.; Nusinow, D.A.; Kay, S.A.; Kunz, H.H.; et al. Identification of Open Stomata1-interacting proteins reveals interactions with Sucrose non-fermenting1-Related Protein Kinases2 and with type 2A protein phosphatases that function in abscisic acid responses. Plant Physiol. 2015, 169, 760-779. [CrossRef] [PubMed]

153. Li, L.; Song, Y.; Wang, K.; Dong, P.; Zhang, X.; Li, F.; Li, Z.; Ren, M. TOR-inhibitor insensitive-1 (TRIN1) regulates cotyledons greening in Arabidopsis. Front. Plant Sci. 2015, 6, 861. [CrossRef] [PubMed]

154. Barrada, A.; Djendli, M.; Desnos, T.; Mercier, R.; Robaglia, C.; Montane, M.H.; Menand, B. A TOR-YAK1 signaling axis controls cell cycle, meristem activity and plant growth in Arabidopsis. Development 2019, 146. [CrossRef]

155. Kim, D.; Ntui, V.O.; Xiong, L. Arabidopsis YAK1 regulates abscisic acid response and drought resistance. FEBS Lett. 2016, 590, 2201-2209. [CrossRef] [PubMed]

156. Yu, F.; Lou, L.; Tian, M.; Li, Q.; Ding, Y.; Cao, X.; Wu, Y.; Belda-Palazon, B.; Rodriguez, P.L.; Yang, S.; et al. ESCRT-I component VPS23A affects ABA signaling by recognizing ABA receptors for endosomal degradation. Mol. Plant 2016, 9, 1570-1582. [CrossRef] [PubMed]

157. Belda-Palazon, B.; Rodriguez, L.; Fernandez, M.A.; Castillo, M.C.; Anderson, E.M.; Gao, C.; Gonzalez-Guzman, M.; Peirats-Llobet, M.; Zhao, Q.; De Winne, N.; et al. FYVE1/FREE1 interacts with the PYL4 ABA receptor and mediates its delivery to the vacuolar degradation pathway. Plant Cell 2016, 28, 2291-2311. [CrossRef] [PubMed] 
158. Gao, C.; Zhuang, X.; Cui, Y.; Fu, X.; He, Y.; Zhao, Q.; Zeng, Y.; Shen, J.; Luo, M.; Jiang, L. Dual roles of an Arabidopsis ESCRT component FREE1 in regulating vacuolar protein transport and autophagic degradation. Proc. Natl. Acad. Sci. USA 2015, 112, 1886-1891. [CrossRef] [PubMed]

159. Garcia-Leon, M.; Cuyas, L.; El-Moneim, D.A.; Rodriguez, L.; Belda-Palazon, B.; Sanchez-Quant, E.; Fernandez, Y.; Roux, B.; Zamarreno, A.M.; Garcia-Mina, J.M.; et al. Arabidopsis ALIX regulates stomatal aperture and turnover of abscisic acid receptors. Plant Cell 2019, 31, 2411-2429. [CrossRef]

160. Yu, F.; Cao, X.; Liu, G.; Wang, Q.; Xia, R.; Zhang, X.; Xie, Q. ESCRT-I component VPS23A is targeted by E3 ubiquitin ligase XBAT35 for proteasome-mediated degradation in modulating ABA signaling. Mol. Plant 2020, 13, 1556-1569. [CrossRef]

161. Xia, F.N.; Zeng, B.; Liu, H.S.; Qi, H.; Xie, L.J.; Yu, L.J.; Chen, Q.F.; Li, J.F.; Chen, Y.Q.; Jiang, L.; et al. SINAT E3 ubiquitin ligases mediate FREE1 and VPS23A degradation to modulate abscisic acid signaling. Plant Cell 2020, 32, 3290-3310. [CrossRef] [PubMed]

162. Seo, D.H.; Ahn, M.Y.; Park, K.Y.; Kim, E.Y.; Kim, W.T. The N-terminal UND motif of the Arabidopsis U-box E3 ligase PUB18 is critical for the negative regulation of ABA-mediated stomatal movement and determines Its ubiquitination specificity for exocyst subunit Exo70B1. Plant Cell 2016, 28, 2952-2973. [CrossRef]

163. Jurkiewicz, P.; Batoko, H. Protein degradation mechanisms modulate abscisic acid signaling and responses during abiotic stress. Plant Sci. 2018, 267, 48-54. [CrossRef]

164. Mucha, E.; Fricke, I.; Schaefer, A.; Wittinghofer, A.; Berken, A. Rho proteins of plants-Functional cycle and regulation of cytoskeletal dynamics. Eur. J. Cell Biol. 2011, 90, 934-943. [CrossRef] [PubMed]

165. Nagawa, S.; Xu, T.; Yang, Z. RHO GTPase in plants: Conservation and invention of regulators and effectors. Small GTPases 2010, 1, 78-88. [CrossRef]

166. Vanhee, C.; Batoko, H. Autophagy involvement in responses to abscisic acid by plant cells. Autophagy 2011, 7, 655-656. [CrossRef]

167. Li, H.; Li, Y.; Zhao, Q.; Li, T.; Wei, J.; Li, B.; Shen, W.; Yang, C.; Zeng, Y.; Rodriguez, P.L.; et al. The plant ESCRT component FREE1 shuttles to the nucleus to attenuate abscisic acid signalling. Nat. Plants 2019, 5, 512-524. [CrossRef] [PubMed]

168. Yamauchi, S.; Mano, S.; Oikawa, K.; Hikino, K.; Teshima, K.M.; Kimori, Y.; Nishimura, M.; Shimazaki, K.I.; Takemiya, A. Autophagy controls reactive oxygen species homeostasis in guard cells that is essential for stomatal opening. Proc. Natl. Acad. Sci. USA 2019, 116, 19187-19192. [CrossRef] [PubMed]

169. Huang, L.; Yu, L.J.; Zhang, X.; Fan, B.; Wang, F.Z.; Dai, Y.S.; Qi, H.; Zhou, Y.; Xie, L.J.; Xiao, S. Autophagy regulates glucosemediated root meristem activity by modulating ROS production in Arabidopsis. Autophagy 2019, 15, 407-422. [CrossRef] [PubMed]

170. Bi, C.; Ma, Y.; Wu, Z.; Yu, Y.T.; Liang, S.; Lu, K.; Wang, X.F. Arabidopsis ABI5 plays a role in regulating ROS homeostasis by activating CATALASE 1 transcription in seed germination. Plant Mol. Biol. 2017, 94, 197-213. [CrossRef]

171. Yu, Y.; Wang, J.; Li, S.; Kakan, X.; Zhou, Y.; Miao, Y.; Wang, F.; Qin, H.; Huang, R. Ascorbic acid integrates the antagonistic modulation of ethylene and abscisic acid in the accumulation of reactive oxygen species. Plant Physiol. 2019, 179, 1861-1875. [CrossRef] [PubMed]

172. Schieke, S.M.; Finkel, T. Mitochondrial signaling, TOR, and life span. Biol. Chem. 2006, 387, 1357-1361. [CrossRef]

173. Zubo, Y.O.; Schaller, G.E. Role of the cytokinin-activated type-B response regulators in hormone crosstalk. Plants 2020, $9,166$. [CrossRef]

174. Acheampong, A.K.; Shanks, C.; Cheng, C.Y.; Schaller, G.E.; Dagdas, Y.; Kieber, J.J. EXO70D isoforms mediate selective autophagic degradation of type-A ARR proteins to regulate cytokinin sensitivity. Proc. Natl. Acad. Sci. USA 2020, 117, 27034-27043. [CrossRef] [PubMed]

175. Wang, Y.; Li, L.; Ye, T.; Zhao, S.; Liu, Z.; Feng, Y.Q.; Wu, Y. Cytokinin antagonizes ABA suppression to seed germination of Arabidopsis by downregulating ABI5 expression. Plant J. Cell Mol. Biol. 2011, 68, 249-261. [CrossRef] [PubMed]

176. Lv, M.; Li, J. Molecular mechanisms of brassinosteroid-mediated responses to changing environments in Arabidopsis. Int. J. Mol. Sci. 2020, 21, 2737. [CrossRef] [PubMed]

177. Nolan, T.M.; Vukasinovic, N.; Liu, D.; Russinova, E.; Yin, Y. Brassinosteroids: Multidimensional regulators of plant growth, development, and stress responses. Plant Cell 2020, 32, 295-318. [CrossRef]

178. Planas-Riverola, A.; Gupta, A.; Betegon-Putze, I.; Bosch, N.; Ibanes, M.; Cano-Delgado, A.I. Brassinosteroid signaling in plant development and adaptation to stress. Development 2019, 146. [CrossRef]

179. Wei, Z.; Li, J. Regulation of brassinosteroid homeostasis in higher plants. Front. Plant Sci. 2020, 11, 583622. [CrossRef]

180. $\mathrm{Hu}, \mathrm{Y}$; $Y$ Yu, D. BRASSINOSTEROID INSENSITIVE2 interacts with ABSCISIC ACID INSENSITIVE5 to mediate the antagonism of brassinosteroids to abscisic acid during seed germination in Arabidopsis. Plant Cell 2014, 26, 4394-4408. [CrossRef]

181. Jiang, H.; Tang, B.; Xie, Z.; Nolan, T.; Ye, H.; Song, G.Y.; Walley, J.; Yin, Y. GSK3-like kinase BIN2 phosphorylates RD26 to potentiate drought signaling in Arabidopsis. Plant J. Cell Mol. Biol. 2019, 100, 923-937. [CrossRef] [PubMed]

182. Cai, Z.; Liu, J.; Wang, H.; Yang, C.; Chen, Y.; Li, Y.; Pan, S.; Dong, R.; Tang, G.; Barajas-Lopez Jde, D.; et al. GSK3-like kinases positively modulate abscisic acid signaling through phosphorylating subgroup III SnRK2s in Arabidopsis. Proc. Natl. Acad. Sci. USA 2014, 111, 9651-9656. [CrossRef] [PubMed]

183. Wang, H.; Tang, J.; Liu, J.; Hu, J.; Liu, J.; Chen, Y.; Cai, Z.; Wang, X. Abscisic acid signaling inhibits brassinosteroid signaling through dampening the dephosphorylation of BIN2 by ABI1 and ABI2. Mol. Plant 2018, 11, 315-325. [CrossRef] 
184. Xiong, F.; Zhang, R.; Meng, Z.; Deng, K.; Que, Y.; Zhuo, F.; Feng, L.; Guo, S.; Datla, R.; Ren, M. Brassinosteriod Insensitive 2 (BIN2) acts as a downstream effector of the Target of Rapamycin (TOR) signaling pathway to regulate photoautotrophic growth in Arabidopsis. New Phytol. 2017, 213, 233-249. [CrossRef] [PubMed]

185. Nolan, T.M.; Brennan, B.; Yang, M.; Chen, J.; Zhang, M.; Li, Z.; Wang, X.; Bassham, D.C.; Walley, J.; Yin, Y. Selective autophagy of BES1 mediated by DSK2 balances plant growth and survival. Dev. Cell 2017, 41, 33-46.e37. [CrossRef] [PubMed]

186. Chi, C.; Li, X.; Fang, P.; Xia, X.; Shi, K.; Zhou, Y.; Zhou, J.; Yu, J. Brassinosteroids act as a positive regulator of NBR1-dependent selective autophagy in response to chilling stress in tomato. J. Exp. Bot. 2020, 71, 1092-1106. [CrossRef] [PubMed] 